\title{
Investigating the effects of food matrix and food components on bioaccessibility of pomegranate (Punica granatum) phenolics and anthocyanins using an in-vitro gastrointestinal digestion model
}

\author{
Hafizenur Sengul ${ }^{a}$, Ece Surek ${ }^{\mathrm{a}, \mathrm{b}}$, Dilara Nilufer-Erdil ${ }^{\mathrm{a}, *}$ \\ a Istanbul Technical University, Faculty of Chemical and Metallurgical Engineering, Department of Food Engineering, 34469, Maslak, Istanbul, Turkey \\ ${ }^{\mathrm{b}}$ Izmir Institute of Technology, Faculty of Engineering, Department of Food Engineering, 35430, Gulbahce, Urla, Izmir, Turkey
}

\section{A R T I C L E I N F O}

\section{Article history:}

Received 4 March 2014

Accepted 30 May 2014

Available online 7 June 2014

\section{Keywords:}

Anthocyanins

Phenolics

Bioaccessibility

Food matrix

Pomegranate

In-vitro digestion

\begin{abstract}
A B S T R A C T
Effects of food matrix and individual food components on potential bioaccessibility of pomegranate were investigated by means of simulating in vitro gastrointestinal (GI) digestion. The foodstuffs (sunflower oil, skim milk, cooked lean meat, bread, skim yogurt, probiotic yogurt, apple, lemon, honey, soy milk, cream, and soybean) and the food components (gluten, casein, isolated meat protein, lactose, fructose, galactose, glucose, salt, ascorbic acid, starch, cooked starch, tocopherol, linoleic acid, cellulose, citric acid and pectin) were codigested with pomegranate in model systems to better understand matrix effects. Total phenolic content (TPC) and total anthocyanin content (TAC) were determined by spectrophotometric methods and major phenolics/anthocyanins were analyzed by RP-HPLC/PDA detection both before and after in vitro GI digestion at post gastric (PG), dialyzable (IN) and non-dialyzable (OUT) fractions. Phenolics of pomegranate were found to be stable during gastric conditions (115\%), with $25 \%$ loss in pancreatic digestion, available (14\%) in IN. Although preserved (89\%) in PG, anthocyanins were lost in pancreatic digestion (38\%), but still available (12\%) in IN. Milk, bread, yogurt, probiotic yogurt, lactose, starch, cellulose, salt, citric acid or tocopherol codigestion with pomegranate decreased TPC for all fractions. Proteins affected losses in PG and OUT fractions. Carbohydrates such as starch, lactose, glucose and pectin appeared to affect the loss of phenolics and exerted 2-fold decreases in serum fraction (IN). For TAC, only meat, soymilk or cream codigestion with pomegranate resulted in IN losses. Proteins did not significantly affect TAC in IN, but were inhibitory in PG. However, carbohydrates and fatty acids significantly increased TAC in IN. Generally cyanidins were found to be more stable in food matrices and pancreatic conditions than other anthocyanins.
\end{abstract}

(c) 2014 Elsevier Ltd. All rights reserved.

\section{Introduction}

Pomegranate (Punica granatum) is an important functional fruit due to its high antioxidant potential. Major phenolic compounds in pomegranate are anthocyanins, hydrolysable tannins and phenolic acids such as ellagic acid and its derivatives (Gil-Izquierdo, Tomas-Barberan, Hess-Pierce, Holcroft, \& Kader, 2000). Phenolic compounds and polyphenols have antimutagenic and anticarcinogenic properties. Moreover, they are protective against cardiovascular diseases. There are several studies showing high antioxidant activity, antitumoral and anticarcinogenic properties of pomegranate (Gil-Izquierdo et al., 2000; Seeram et al., 2005).

Bioavailability is generally defined as the proportion of the nutrient that is digested, absorbed and metabolized through normal pathways

\footnotetext{
* Corresponding author. Tel.: +90212 285 7342; fax: +90212 2857333 .

E-mail address: niluferd@itu.edu.tr (D. Nilufer-Erdil).
}

(McGhie \& Walton, 2007). When evaluating the potential functionality of a compound its bioavailability in food is more important than the quantity of that compound. Research concerning the bioaccessibility of phenolic compounds and other antioxidants from solid matrices is important, since only the compounds released from the food matrix and/ or absorbed in the small intestine are potentially bioavailable and able to exert their beneficial effects (Tagliazucchi, Verzelloni, Bertolini, \& Conte, 2009). In vivo studies are much more complicated to carry out research on bioavailability and are affected from differences in human or animal models. Their higher cost and ethical concerns are additional problems. Results of in vitro digestion models are often different from those of in vivo models as it is difficult to accurately simulate the complex physiological events taking place in living organisms (Hur, Lim, Decker, \& McClements, 2011). Because in vitro studies offer advantages such as simplicity, ease of application and low cost to the investigator, they are preferred than in vivo studies (Yi, Akoh, Fischer, \& Krewer, 2006).

In the literature, limited research is available on in vitro bioavailability studies that investigate the effect of food matrices on phenolic 
compound absorption (Cebeci \& Sahin-Yesilcubuk, 2014; Dupas, Marsset-Baglieri, Ordonaud, Ducept, \& Maillard, 2006; Langley-Evans, 2000; Larkin, Price, \& Astheimer, 2007; McDougall, Dobson, Smith, Blake, \& Stewart, 2005; Mullen, Edwards, Serafini, \& Crozier, 2008; Neilson et al., 2009; Ortega, Reguant, Romero, Macia, \& Motilva, 2009; Serafini et al., 2009). Further studies are needed to gain insight into the mechanisms underlying the interactive effects of anthocyanins and food components on anthocyanin bioavailability and antioxidant capacity at the physiological level (Yang, Koo, Song, \& Chun, 2011).

According to the research by McDougall et al. (2005) when raspberries were consumed with other foods such as bread, breakfast cereals, ice cream or cooked steak, postgastric digestion decreased phenolic compounds; however anthocyanin content was not affected (McDougall et al., 2005). The addition of milk or the fat content of milk showed no significant effect on the antioxidant activity of coffee samples (Dupas et al., 2006). On the other hand, the addition of milk to tea and the addition of milk fat to blueberry extract affected antioxidant capacity (Langley-Evans, 2000; Serafini et al., 2009). Bioavailability of pelargonidin 3-O-glucoside was higher when strawberries were consumed with cream due to positive effect of the fat in cream on the absorption of strawberries in metabolism (Mullen et al., 2008). Composition of the food matrix in which polyphenols are located seems to be a factor in their stability and digestibility. These findings are significant from the point of nutrition because the digestibility and bioavailability can be modified by dietary nutrients such as proteins, lipids, dietary fiber, carbohydrates, minerals and others that are present in the food matrix (Ortega et al., 2009).

The objective of this study is to understand how food matrix and individual food components affect the digestibility of phenolics and especially the anthocyanins found in pomegranate fruit (one of the richest sources of phenolics) by using in vitro gastrointestinal digestion model. By this research, the potential stability and bioavailability of phenolic compounds and anthocyanins in pomegranate during digestion and the changes that take place through interactions between bioactive compounds available in pomegranate and other components of commonly consumed foods will be determined.

\section{Materials and methods}

\subsection{Materials}

Pomegranate fruits (Hicaz Nar variety) were obtained from two different local markets in Istanbul, Turkey. After removing the peels, pomegranate arils (control) were separated and milled under liquid nitrogen by using a grinder (IKA A11, Germany) and ground samples were stored at $-80{ }^{\circ} \mathrm{C}$. Sunflower oil, UHT milk (skim milk, with fat content about $0.1 \%$ ), minced lean meat, bread, skim plain yogurt (with fat content about $0.15 \%$ ), probiotic yogurt, red apple, lemon, honey, soy milk, cream, soybean, and wheat starch were the other materials used for the model systems and were also obtained from supermarkets. All food materials were stored under proper conditions until use and analysis.

\subsection{Chemicals and ingredients}

Methanol, formic acid, sodium carbonate, sodium hydroxide, hydrochloric acid (37\%), sodium acetate trihydrate, trifluoroacetic acid (TFA), citric acid and sodium chloride (salt) were purchased from Merck (Darmstadt, Germany). Lactose, fructose, galactose, glucose, ascorbic acid, tocopherol (Vit E), cellulose, pectin, gallic acid, Folin-Ciocalteu reagent, ethanol, pepsin, pancreatin, bile salts, acetonitrile and HPLC standards such as pelargonidin 3-0-glucoside were obtained from Sigma-Aldrich (Steinheim, Germany). Sodium bicarbonate from BDH Chemicals Ltd (Poole, UK), potassium chloride from Riedel-de Haen (Hanover, Germany) and linoleic acid (Fluka, Switzerland) were also used. Cyanidin 3-O-glucoside, pelargonidin 3,5-di-O-glucoside, cyanidin 3,5-di-O-glucoside, delphinidin 3-O-glucoside and delphinidin 3,5-di-O-glucoside were supplied from Extrasynthese (Genay, France) to use as HPLC standards.

Food components such as gluten (Doruk Marmara Flour Company, Turkey), soy protein isolate (Royal Food Distribution Marketing Import and Export Co., Turkey) and casein (Milkon Milk and Food Products Co., Sakarya, Turkey) were also supplied from domestic companies.

\subsection{Extraction of phenolic compounds}

Extraction of polyphenols from milled pomegranate arils was carried out (as controls) to determine the initial values and compare the changes in total phenolic and anthocyanin contents for samples after in vitro gastrointestinal ( $\mathrm{GI}$ ) digestion. Extractions were performed both by distilled water and aqueous methanolic solution. To simulate the conditions in GI digestion distilled water extract was selected as control. But methanolic solutions are typically used during chemical analysis of bioactive compounds and therefore gastrointestinal digestion of methanolic extracts was also carried out. The extraction method was modified from Bino et al. (2005). One gram of milled pomegranate aril was weighed in test tubes under liquid nitrogen. $5 \mathrm{ml}$ of $75 \%$ methanol:water solution with $0.1 \%$ formic acid or the same amount of distilled water was added to each tube and vortexed for $1 \mathrm{~min}$. Samples were sonicated for $15 \mathrm{~min}$ in an ultrasonic bath (Ultrasonic Cleaner-VWR) and centrifuged (Hettich Universal 32, Tuttlingen, Germany) at $4000 \mathrm{rpm}$ under $4{ }^{\circ} \mathrm{C}$ for $10 \mathrm{~min}$. This procedure was repeated 4 times until $20 \mathrm{ml}$ of extract was collected. Duplicate extractions were made for each sample. Extracts were stored at $-20{ }^{\circ} \mathrm{C}$ until analysis.

\subsection{Preparation of model systems}

Model systems composed of both commonly consumed foods and food components were developed to investigate the matrix effect on phenolic and anthocyanin bioavailability of pomegranate.

Food materials such as sunflower oil, skim milk, skim yogurt, probiotic yogurt, honey, soy milk and cream were added to test tubes without any pretreatment. Apple was peeled and grated. Lemon was squeezed to obtain the lemon juice. Bread crusts were removed from the bread and ground for bread crumbs. Lean minced meat (beef) was roasted for $20 \mathrm{~min}$. Soybeans were blanched in boiling water for $20 \mathrm{~min}$. To simulate the food consumption, lean meat and soybeans were cooked and solid foods (bread and apple) were ground before analysis.

Starch was mixed with water, cooked at $90{ }^{\circ} \mathrm{C}$ for $5 \mathrm{~min}$ and then cooled. For the isolation of meat protein the method of Santiago, Carrara, and González (2005) was used.

For combinations of solid food materials, $5 \mathrm{~g}$ of ground pomegranate arils and $5 \mathrm{~g}$ of test material were weighed in a glass beaker under liquid nitrogen and $20 \mathrm{ml}$ of distilled water was added. For liquid foods, $5 \mathrm{ml}$ of test sample was mixed with $5 \mathrm{~g}$ of ground pomegranate arils and $15 \mathrm{ml}$ of distilled water was added to obtain a homogenized mixture.

For combinations of food components, $1 \mathrm{~g}$ of ground pomegranate arils and $5 \mathrm{~g}$ of test material were weighed in a glass beaker under liquid nitrogen and $20 \mathrm{ml}$ of distilled water was added.

\subsection{In vitro GI digestion simulation}

In vitro GI digestion method of McDougall et al. (2005) was used to investigate the potential bioavailability of phenolics and anthocyanins in pomegranate, both for control samples and model systems. Digestion was performed by enzymes and absorption was simulated by using dialysis tubing. The method includes two different stages of digestion: gastric and small intestine conditions. Gastric conditions were simulated by pepsin- $\mathrm{HCl}$ digestion and small intestine conditions were obtained by bile salts-pancreatin digestion. 315 units/ml of pepsin was used to prepare pepsin solution and $1.5 \mathrm{ml}$ of this solution was added to control sample and model systems in distilled water. Sample solution $\mathrm{pH}$ 
was adjusted to 1.7 by using $5 \mathrm{M} \mathrm{HCl}$ and incubated for $2 \mathrm{~h}$ in a shaking water bath (Memmert, Germany) at $37{ }^{\circ} \mathrm{C}$ and $100 \mathrm{rpm}$. After $2 \mathrm{~h}$, gastric digestion was completed and $2 \mathrm{ml}$ of the solution was removed (PG: postgastric fraction-the solution leaving the stomach). $4.5 \mathrm{ml}$ of $4 \mathrm{mg} / \mathrm{ml}$ pancreatin and $4.5 \mathrm{ml}$ of $25 \mathrm{mg} / \mathrm{ml}$ bile salt mixture were added to the remainder in the glass beaker. A piece of cellulose dialysis tubing (molecular mass cutoff, $12 \mathrm{kDa}$, Sigma) was cut and filled with $20 \mathrm{ml}$ of $1 \mathrm{M} \mathrm{NaHCO}_{3}$ to neutralize the sample. After 2 $\mathrm{h}$ of incubation in shaking water bath at $37{ }^{\circ} \mathrm{C}$ and $100 \mathrm{rpm}$, the solution outside the tubing was taken as non-serum available fraction (OUT: solution outside of the dialysis tubing). The solution entering the tubing was taken as serum available fraction (IN: solution entering the dialysis tubing). PG, IN and OUT samples were stored at $-20{ }^{\circ} \mathrm{C}$ until further analysis. They were thawed and centrifuged at $16,000 \mathrm{rpm}$ for $20 \mathrm{~min}$ and supernatants were separated to be used for analysis.

Results obtained for methanolic extracts (control) were assumed as $100 \%$ and recovery $\%$ values were calculated from these data for all fractions. LOSS values calculated for total phenolic contents (TPC) and total anthocyanin contents (TAC) represent the losses during pancreatic digestion which are obtained by subtracting IN and OUT fraction values from the PG values (LOSS = PG - IN-OUT). For all samples, digestions were carried out in duplicate. TPC analysis by Folin-Ciocalteu method, TAC analysis by $\mathrm{pH}$ differential method and major anthocyanin analysis by HPLC-PDA were carried out at PG, IN and OUT fractions of all model systems and the extracts.

Foodstuff and food components without pomegranate were used as control digestions to monitor changes in phenolics. These control digestion values for food matrices and also single pomegranate digestion controls were compared with either codigested pomegranate + foodstuff or codigested pomegranate + food component values to evaluate the differences between the mathematically calculated "expected" phenolic content (single pomegranate value + single foodstuff of food component values in concern) values and the analyzed "found" values for codigested pomegranate + foodstuff or food component. The reason for making such calculation is that the methods used for analysis of phenolics can be affected by the phenolics present in the foodstuffs or food components or some of the components can react with FolinCiocalteu reagent in the same manner as phenolic compounds. The anthocyanin content in foodstuffs and food components was also analyzed after digestion and no anthocyanins were detected; therefore, the anthocyanins measured were assumed to be only from the pomegranate extracts.

\subsection{Total phenolic and total anthocyanin content analysis}

Total phenolic and total anthocyanin contents were analyzed by a UV-Visible spectrophotometer (Shimadzu, Kyoto, Japan). Total phenolic content (TPC) was determined by using Folin-Ciocalteu method as described by Velioglu, Mazza, Gao, and Oomah (1998). Gallic acid was used to prepare the calibration curve and the results were expressed in mg gallic acid equivalents (GAE) per $100 \mathrm{~g}$ of edible fruit.

While analyzing codigested samples, since the food matrices tested can involve phenolic compounds or some other compounds may react with the Folin-Ciocalteu reagent, expected and found values were compared with each other to see the real effects of the food matrix. For this reason each food was tested alone for their total phenolic contents with the same method and the values obtained for both single pomegranate and each foodstuff were summed up to find the expected (E) value, whereas the found $(F)$ value was obtained directly by measuring the codigested sample.

For measuring total anthocyanin content (TAC) pH differential method was used as described by Kar, Ferchichi, Attia, and Bouajila (2011). Results were expressed as mg cyanidin 3-0-glucoside (cyn-3glu) equivalent/100 g edible fruit.

\subsection{HPLC-PDA analysis of major anthocyanins}

Anthocyanin profiles of all extracts and in vitro digestion samples were determined by High Performance Liquid Chromatography with Photo Diode Array (HPLC-PDA) detection. External standards were used to prepare standard calibration curves. Samples or extracts obtained from in vitro digestion were acidified to $0.5 \%$ trifluoroacetic acid (TFA) (v/v) by using 10\% TFA and mixed well. After centrifuging they were filtrated through a $0.45-\mu \mathrm{m}$ membrane filter and placed into vials. Samples were analyzed in a Waters 2695 HPLC system with PDA (Waters 2996) detection. Luna C18 column $(150 \times 4.60 \mathrm{~mm}$, pore size $100 \AA$ A, particle size $5 \mu \mathrm{m}$ ) from Phenomenex (Torrance, CA, USA) was used as the stationary phase. The mobile phase was solvent A, Milli-Q water with $0.1 \%(\mathrm{v} / \mathrm{v})$ TFA and solvent $\mathrm{B}$, acetonitrile with $0.1 \%(\mathrm{v} / \mathrm{v})$ TFA. A linear gradient was used as follows: at $0 \mathrm{~min}, 95 \%$ solvent A and $5 \%$ solvent B; at $45 \mathrm{~min}, 65 \%$ solvent $\mathrm{A}$ and $35 \%$ solvent $\mathrm{B}$; at $47 \mathrm{~min}, 25 \%$ solvent $A$ and $75 \%$ solvent $B$; and at $54 \mathrm{~min}$, returns to initial conditions. The flow rate was $1 \mathrm{ml} / \mathrm{min}$. Detections were done at 280 , 312,360 , and $512 \mathrm{~nm}$ wavelengths. Identification was based on the retention times and characteristic UV spectra. Quantification was performed by using calibration curves obtained for standards and the results were expressed as $\mathrm{mg} / 100 \mathrm{~g}$ edible fruit.

\subsection{Statistical analysis}

All of the analyses were carried out in triplicate for each sample. The results were reported as mean value \pm standard deviation and evaluated statistically by using one way analysis of variance (ANOVA). Whenever significant differences were detected $(p<0.05)$, means were subjected to Duncan's New Multiple Range Test. When analyzing the data for total phenolics after GI digestion, the significant differences between the expected and found values were evaluated by paired $t$ test for each sample tested. All analyses were performed with Statistical Package for the Social Sciences software (version 16.0, SPSS Inc., Chicago, IL).

\section{Results and discussion}

\subsection{Total phenolic and anthocyanin contents of pomegranate extracts before and after GI digestion}

Total phenolic and anthocyanin contents of pomegranate arils both before (extracted with both distilled water or $75 \%$ methanol:water with $0.1 \%$ formic acid-controls) and after GI digestion (PG, OUT and IN fractions) were determined as shown in Table 1. It was accepted that phenolics and anthocyanins were extracted efficiently by using methanol, so it was assumed as $100 \%$. Aqueous extracts were also measured due to the availability of water in the digestive system as the solvent. TPC of aqueous pomegranate extract (108.1 $\pm 4.3 \mathrm{mg} \mathrm{GAE} / 100 \mathrm{~g}$ fruit) was found to be significantly lower than (about 59.8\%) that of methanolic extract $(180.7 \pm 0.6 \mathrm{mg} \mathrm{GAE} / 100 \mathrm{~g}$ edible fruit). TPC value of pomegranate was lower than that in the study of Wolfe et al. (2008) (338 $\pm 14 \mathrm{mg} \mathrm{GAE} / 100 \mathrm{~g}$ edible fruit) which used acetone for extraction. On the other hand, it was higher than the value obtained by Karadeniz, Burdurlu, Koca, and Soyer (2005) (240.8 mg/kg fruit). Also it was declared that phenolic contents of fruits may change according to variety and growth conditions (Fazzari et al., 2008). After GI digestion, significant differences were found for TPC between the PG, OUT and IN fractions $(p<0.05)$. Generally, IN fraction had the lowest TPC value $(25.7 \pm 0.0 \mathrm{mg}$ GAE$/ 100 \mathrm{~g}$ edible fruit) whereas PG showed the highest value (207.4 $\pm 5.5 \mathrm{mg} \mathrm{GAE} / 100 \mathrm{~g}$ edible fruit) even greater than that of the initial methanolic extract. After gastric digestion, phenolic content increased by the effect of gastric acid as reported by Perez-Vicente, Gil-Izquierdo, and Garcia-Viguera (2002).

TAC of pomegranate methanolic extract was measured as $13.2 \pm$ $2.4 \mathrm{mg}$ cyn 3-0-glu/100 g edible fruit, which was in accordance with 
Table 1

Total phenolic and total anthocyanin contents of pomegranate extracts and samples before and after in vitro GI digestion with relative distributions (recovery \%) between fractions.

\begin{tabular}{|c|c|c|c|c|c|}
\hline & & TPC $\%$ & TPC (mg GAE/100 g edible fruit) & TAC $\%$ & TAC (mg cyn-3glu/100 g edible fruit) \\
\hline Initial methanolic extract & & 100 & $180.7 \pm 0.6^{\mathrm{b}}$ & 100 & $13.2 \pm 2.4^{\mathrm{a}}$ \\
\hline Initial aqueous extract & & 59.8 & $108.1 \pm 4.3^{\mathrm{c}}$ & 89.4 & $11.8 \pm 2.1^{\mathrm{a}}$ \\
\hline \multirow[t]{4}{*}{ In vitro GI digestion samples } & PG & 114.8 & $207.4 \pm 5.5^{\mathrm{a}}$ & 89.3 & $11.8 \pm 0.6^{\mathrm{a}}$ \\
\hline & IN & 14.2 & $25.7 \pm 0.0^{\mathrm{d}}$ & 11.7 & $1.6 \pm 0.1^{\mathrm{c}}$ \\
\hline & OUT & 75.6 & $136.7 \pm 13.6^{c}$ & 39.8 & $5.3 \pm 0.5^{b}$ \\
\hline & LOSS & 24.9 & - & 38.4 & - \\
\hline
\end{tabular}

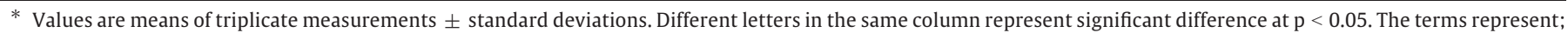

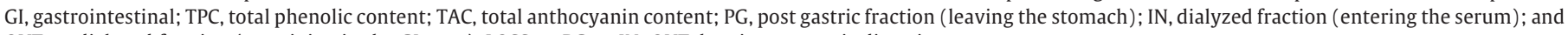
OUT, undialyzed fraction (remaining in the GI tract). LOSS = PG - IN-OUT, loss in pancreatic digestion.

the study of Tehranifor, Zarei, Nemati, Esfandiyari, and Vazifeshenas (2010). No significant difference was observed both in each initial extract and between the extracts and PG fraction ( $p>0.05)$; however changes between fractions after gastric digestion were found significant $(p<0.05)$. These findings are in agreement with Liang et al. (2012) who found similarly that during gastric digestion anthocyanins were recovered to a great degree (98\%) in mulberry but got significantly lost after intestinal digestion. In the present work, the recovery \% values for TAC for the OUT and IN fractions after pancreatic digestion were determined as $39.8 \%$ and $11.7 \%$, respectively. Losses during pancreatic digestion were thought to be due to an increase in pH. McDougall et al. (2005) reported that for raspberry anthocyanins, $70 \%$ and $5 \%$ of TAC were recovered during pancreatic digestion (IN + OUT) and in the IN fraction (representing the material entering in serum), respectively. In this research, the TAC of the pancreatic digestion fraction was lower, but the TAC of the IN fraction was higher (51.5\% and $11.7 \%$, respectively).

There was about $25 \%$ loss during pancreatic digestion as only $14.2 \%$ of initial TPC remaining in the extract entered into serum (IN). However for TAC, loss was greater (38.4\%) during pancreatic digestion and only $11.7 \%$ of initial extract passed into serum fraction (IN). As claimed by Perez-Vicente et al. (2002), the loss in TPC during gastric conditions was lower than that in TAC. The higher loss in TAC might be due to the modification of anthocyanins to different phenolic compounds (McDougall et al., 2005). TPC results were highly correlated with the study of Fazzari et al. (2008) in which there was 123\% increase in TPC of cherry extract during gastric digestion; however no important change was observed for TAC. When overall evaluation is made it is evident that phenolic compounds are more stable to GI digestion conditions than anthocyanins, especially in the PG and OUT fractions, and to a lesser extent in IN fraction.

\subsection{Analysis of major phenolics and anthocyanins in pomegranate extracts before and after GI digestion}

Amounts of major phenolics and anthocyanins identified in pomegranate extracts before and after simulated GI digestion are given in Table 2. Punicalagin A (11.6-12.2 mg/100 g edible fruit), chlorogenic acid (3.3-3.6 mg/100 g edible fruit) and gallic acid $(0.8-1.1 \mathrm{mg} / 100 \mathrm{~g}$ edible fruit) were the major phenolics identified in extracts. To a lesser extent, ferulic acid and caffeic acid (about $0.7 \mathrm{mg} / 100 \mathrm{~g}$ edible fruit) were also identified. For each major phenolic compound no significant difference was obtained between extracts and in PG fraction ( $p>0.05$ ). However, for punicalagin A, ferulic acid, chlorogenic acid and caffeic acid, IN and OUT fractions significantly differed from PG fraction or extracts $(\mathrm{p}<0.05)$. Only for gallic acid, IN fraction was not different than extracts or PG fraction ( $p>0.05)$.

Major anthocyanins determined in pomegranate in decreasing order according to their contents were: pelargonidin 3,5-di-O-glucoside (pel 3,5-di-O-glu), cyanidin 3,5-di-O-glucoside (cyn 3,5-di-O-glu), delphinidin 3,5-di-O-glucoside (del 3,5-di-O-glu), cyanidin 3-Oglucoside (cyn-3-glu) and pelargonidin 3-0 glucoside (pel 3-0-glu). Cyn-3-glu and pel 3-0-glu were also identified by Hernandez, Melgarejo, Tomas-Barberon, and Artes (1999) and Prakash and Prakash (2011). Although pel 3-O-glu could not be detected in extracts, it was identified at very low amounts $(0.5 \pm 0.1 \mathrm{mg} / 100 \mathrm{~g}$ fruit $)$ after in vitro GI digestion. For each major anthocyanin compound no significant difference was obtained between extracts and in PG fraction $(p>0.05)$. However, in IN and OUT fractions only cyn 3,5-di-O-glu and at very low levels cyn-3-glu could be identified. Other major anthocyanins were either lost in those fractions or converted into other compounds.

Table 2

Changes in major phenolics and anthocyanins of pomegranate extracts and samples before and after in vitro GI digestion.

\begin{tabular}{|c|c|c|c|c|c|c|}
\hline \multicolumn{7}{|c|}{ Major phenolics (mg/100 g edible fruit) } \\
\hline & & Gallic acid & Punicalagin A & Ferulic acid & Chlorogenic acid & Caffeic acid \\
\hline Methanolic extract & & $0.8 \pm 0.4^{\mathrm{a}}$ & $11.6 \pm 1.5^{\mathrm{a}}$ & $0.7 \pm 0.1^{\mathrm{a}}$ & $3.6 \pm 1.3^{\mathrm{a}}$ & $0.7 \pm 0.4^{\mathrm{a}}$ \\
\hline Aqueous extract & & $1.1 \pm 0.4^{\mathrm{a}}$ & $12.2 \pm 0.7^{\mathrm{a}}$ & $0.7 \pm 0.2^{\mathrm{a}}$ & $3.3 \pm 0.4^{\mathrm{a}}$ & $0.4 \pm 0.1^{\mathrm{a}}$ \\
\hline \multirow{3}{*}{ In vitro GI digestion samples } & PG & $1.1 \pm 0.5^{\mathrm{a}}$ & $9.0 \pm 0.9^{\mathrm{a}}$ & $0.6 \pm 0.0^{\mathrm{a}}$ & $2.6 \pm 0.7^{\mathrm{a}}$ & $0.4 \pm 0.3^{\mathrm{a}}$ \\
\hline & IN & $0.8 \pm 0.0^{\mathrm{a}}$ & $1.6 \pm 0.2^{c}$ & $0.1 \pm 0.0^{\mathrm{b}}$ & $0.5 \pm 0.1^{\mathrm{b}}$ & $0.1 \pm 0.0^{\mathrm{b}}$ \\
\hline & OUT & $0.4 \pm 0.3^{\mathrm{b}}$ & $3.9 \pm 0.4^{b}$ & $0.1 \pm 0.0^{\mathrm{b}}$ & $0.8 \pm 0.3^{b}$ & $0.1 \pm 0.1^{b}$ \\
\hline \multicolumn{7}{|c|}{ Major anthocyanins (mg/100 $\mathrm{g}$ edible fruit) } \\
\hline \multirow{6}{*}{$\begin{array}{l}\text { Methanolic extract } \\
\text { Aqueous extract } \\
\text { In vitro GI digestion samples }\end{array}$} & & Del 3.5-di-O-glu & Cyn 3.5-di-O-glu & Pel 3.5-di-O-glu & Cyn-3-glu & Pel 3-O-glu \\
\hline & & $10.4 \pm 0.1^{\mathrm{a}}$ & $14.3 \pm 4.1^{\mathrm{a}}$ & $20.5 \pm 5.3^{a}$ & $5.6 \pm 0.3^{\mathrm{a}}$ & ND \\
\hline & & $9.6 \pm 4.7^{\mathrm{a}}$ & $14.7 \pm 0.2^{\mathrm{a}}$ & $16.8 \pm 7.6^{\mathrm{a}}$ & $5.3 \pm 0.3^{\mathrm{ab}}$ & ND \\
\hline & PG & $7.9 \pm 1.9^{\mathrm{a}}$ & $11.2 \pm 2.2^{\mathrm{a}}$ & $17.9 \pm 7.9^{\mathrm{a}}$ & $4.7 \pm 0.0^{\mathrm{b}}$ & $0.5 \pm 0.1$ \\
\hline & IN & ND & $0.9 \pm 0.6^{\mathrm{b}}$ & ND & $0.1 \pm 0.0^{c}$ & ND \\
\hline & OUT & ND & $2.3 \pm 1.7^{\mathrm{ab}}$ & ND & $0.2 \pm 0.0^{c}$ & ND \\
\hline
\end{tabular}



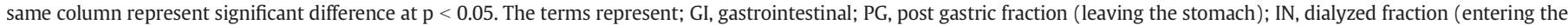

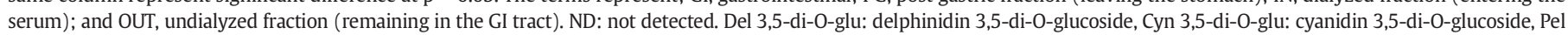
3,5-di-O-glu: pelargonidin 3,5-di-O-glucoside, Cyn-3-glu: cyanidin 3-O-glucoside, and Pel 3-O-glu: pelargonidin 3-O-glucoside. 
Anthocyanins were stable during acidic gastric conditions in this study as observed by McDougall, Fyffe, Dobson, and Stewart (2007). The reason for the low recovery of anthocyanins of red cabbage during pancreatic digestion and increase in amounts of phenolic compounds was explained as the conversion of anthocyanins into other phenolic compounds (McDougall et al., 2007). Cyn 3,5-di-O-glu and cyn-3-glu were more stable and del 3,5-di-O-glu and pel 3,5-di-O-glu could not be determined after pancreatic digestion in this study. Generally most of the anthocyanins decreased in concentration after gastric digestion in this study, however the losses were not found significant $(p>0.05)$. Pel 3,5-di-O-glu level was highest among other anthocyanins in this study, which was different from the findings of Marti, Perez-Vicente,

Table 3

Total phenolic contents (mg GAE/100 g edible fruit) measured by Folin-Ciocalteu method after codigesting pomegranate with other foods and components.

\begin{tabular}{|c|c|c|c|c|c|c|c|}
\hline \multirow[t]{2}{*}{ Samples } & & \multicolumn{2}{|l|}{ PG } & \multicolumn{2}{|l|}{ IN } & \multicolumn{2}{|l|}{ OUT } \\
\hline & & TPC & Effect & TPC & Effect & TPC & Effect \\
\hline Pomegranate control & & $207.4 \pm 8.7$ & & $32.5 \pm 1.2$ & & $129.6 \pm 23.3$ & \\
\hline \multirow[t]{2}{*}{$\mathrm{P}+$ Oil } & $\mathrm{E}$ & $234.6 \pm 8.7$ & $\mathrm{U}$ & $33.3 \pm 1.3$ & $\mathrm{U}$ & $121.5 \pm 28.7$ & $\mathrm{U}$ \\
\hline & $\mathrm{F}$ & $219.1 \pm 17.2$ & & $31.9 \pm 0.1$ & & $165.1 \pm 20.0$ & \\
\hline \multirow[t]{2}{*}{ P + Milk } & $\mathrm{E}$ & $412.3 \pm 15.7$ & I & $91.5 \pm 2.3$ & I & $269.7 \pm 24.8$ & I \\
\hline & $\mathrm{F}$ & $261.3 \pm 9.5$ & & $41.5 \pm 1.6$ & & $192.2 \pm 1.6$ & \\
\hline \multirow[t]{2}{*}{$\mathrm{P}+$ Meat } & $\mathrm{E}$ & $746.0 \pm 20.8$ & $\mathrm{U}$ & $123.4 \pm 0.8$ & $\mathrm{U}$ & $570.2 \pm 29.1$ & I \\
\hline & $\mathrm{F}$ & $691.0 \pm 48.2$ & & $116.4 \pm 6.7$ & & $430.4 \pm 27.1$ & \\
\hline \multirow[t]{2}{*}{$\mathrm{P}+$ Bread } & $\mathrm{E}$ & $457.4 \pm 12.2$ & I & $84.7 \pm 2.6$ & I & $323.7 \pm 24.8$ & I \\
\hline & $\mathrm{F}$ & $251.5 \pm 3.8$ & & $42.1 \pm 3.5$ & & $177.7 \pm 20.9$ & \\
\hline \multirow{2}{*}{$\mathrm{P}+$ Yogurt } & $\mathrm{E}$ & $436.8 \pm 8.7$ & I & $100.1 \pm 1.5$ & I & $303.6 \pm 24.8$ & I \\
\hline & $\mathrm{F}$ & $309.1 \pm 3.3$ & & $44.1 \pm 1.2$ & & $230.3 \pm 4.4$ & \\
\hline \multirow[t]{2}{*}{$\mathrm{P}+$ Probiotic yogurt } & $\mathrm{E}$ & $389.4 \pm 9.0$ & $\mathrm{U}$ & $98.8 \pm 1.1$ & I & $252.1 \pm 23.5$ & $\mathrm{U}$ \\
\hline & $\mathrm{F}$ & $390.3 \pm 33.9$ & & $38.4 \pm 2.3$ & & $215.6 \pm 0.7$ & \\
\hline \multirow[t]{2}{*}{ P + Apple } & $\mathrm{E}$ & $251.2 \pm 8.8$ & $\mathrm{U}$ & $36.1 \pm 0.8$ & I & $138.7 \pm 22.7$ & $\mathrm{U}$ \\
\hline & $\mathrm{F}$ & $219.0 \pm 22.0$ & & $16.0 \pm 1.3$ & & $179.7 \pm 9.8$ & \\
\hline \multirow{2}{*}{$\mathrm{P}+$ Lemon } & E & $308.5 \pm 8.7$ & I & $40.2 \pm 2.1$ & $\mathrm{U}$ & $156.5 \pm 23.8$ & $\mathrm{U}$ \\
\hline & $\mathrm{F}$ & $221.8 \pm 15.8$ & & $32.2 \pm 4.3$ & & $150.6 \pm 8.1$ & \\
\hline \multirow[t]{2}{*}{ P + Honey } & $\mathrm{E}$ & $358.0 \pm 15.2$ & I & $43.6 \pm 1.9$ & $\mathrm{U}$ & $198.6 \pm 24.2$ & I \\
\hline & $\mathrm{F}$ & $247.4 \pm 6.4$ & & $39.0 \pm 2.4$ & & $148.4 \pm 3.4$ & \\
\hline \multirow[t]{2}{*}{$\mathrm{P}+$ Soy milk } & $\mathrm{E}$ & $367.0 \pm 11.9$ & I & $42.6 \pm 2.1$ & $\mathrm{U}$ & $237.2 \pm 24.8$ & I \\
\hline & $\mathrm{F}$ & $231.9 \pm 15.4$ & & $29.3 \pm 12.0$ & & $190.4 \pm 4.0$ & \\
\hline $\mathrm{P}+$ Cream & $\mathrm{E}$ & $302.3 \pm 10.4$ & $\mathrm{U}$ & $34.7 \pm 1.8$ & $\mathrm{U}$ & $196.5 \pm 24.5$ & $\mathrm{U}$ \\
\hline & $\mathrm{F}$ & $302.4 \pm 12.4$ & & $26.6 \pm 1.3$ & & $198.6 \pm 1.0$ & \\
\hline $\mathrm{P}+$ Soybean & $\mathrm{E}$ & $485.7 \pm 33.6$ & I & $84.3 \pm 9.7$ & $\mathrm{U}$ & $240.1 \pm 25.5$ & $\mathrm{U}$ \\
\hline & $\mathrm{F}$ & $384.4 \pm 25.4$ & & $84.9 \pm 10.6$ & & $304.3 \pm 26.9$ & \\
\hline $\mathrm{P}+$ Soy protein & $\mathrm{E}$ & $2520.1 \pm 7.6$ & I & $278.4 \pm 12.2$ & $\mathrm{U}$ & $1924.1 \pm 19.5$ & I \\
\hline & $\mathrm{F}$ & $2083.7 \pm 27.5$ & & $301.6 \pm 28.1$ & & $1552.5 \pm 46.0$ & \\
\hline $\mathrm{P}+$ Casein & $\mathrm{E}$ & $2678.5 \pm 7.6$ & I & $330.2 \pm 4.5$ & $\mathrm{U}$ & $1848.4 \pm 87.6$ & I \\
\hline & $\mathrm{F}$ & $2455.5 \pm 132.0$ & & $354.7 \pm 14.8$ & & $1714.2 \pm 2.0$ & \\
\hline $\mathrm{P}+$ Meat protein & $\mathrm{E}$ & $614.7 \pm 12.5$ & I & $137.2 \pm 5.6$ & $\mathrm{U}$ & $466.7 \pm 21.4$ & I \\
\hline & $\mathrm{F}$ & $434.8 \pm 28.8$ & & $139.9 \pm 10.2$ & & $364.7 \pm 24.6$ & \\
\hline $\mathrm{P}+$ Gluten & $\mathrm{E}$ & $1994.2 \pm 54.7$ & $\mathrm{U}$ & $245.3 \pm 13.7$ & $\mathrm{U}$ & $1351.7 \pm 53.5$ & $\mathrm{P}$ \\
\hline & $\mathrm{F}$ & $1981.5 \pm 84.5$ & & $249.1 \pm 3.3$ & & $1537.3 \pm 99.5$ & \\
\hline $\mathrm{P}+$ Stearic acid & $\mathrm{E}$ & $278.1 \pm 8.0$ & $\mathrm{U}$ & $85.8 \pm 5.9$ & I & $198.8 \pm 14.7$ & $\mathrm{U}$ \\
\hline & $\mathrm{F}$ & $245.6 \pm 8.8$ & & $56.3 \pm 4.2$ & & $173.2 \pm 6.4$ & \\
\hline $\mathrm{P}+$ Linoleic acid & $\mathrm{E}$ & $276.5 \pm 10.2$ & I & $82.5 \pm 44$ & I & $175.1 \pm 16.3$ & $\mathrm{U}$ \\
\hline & $\mathrm{F}$ & $219.3 \pm 0.4$ & & $57.1 \pm 3.5$ & & $172.3 \pm 8.9$ & \\
\hline $\mathrm{P}+$ Starch & $\mathrm{E}$ & $304.4 \pm 7.7$ & I & $108.9 \pm 6.6$ & I & $200.0 \pm 14.8$ & I \\
\hline & $\mathrm{F}$ & $217.6 \pm 11.5$ & & $36.2 \pm 2.5$ & & $124.5 \pm 12.7$ & \\
\hline $\mathrm{P}+$ Cooked starch & $\mathrm{E}$ & $287.4 \pm 14.0$ & I & $76.7 \pm 3.5$ & I & $144.4 \pm 14.4$ & I \\
\hline & $\mathrm{F}$ & $155.7 \pm 9.7$ & & $36.9 \pm 0.6$ & & $77.1 \pm 10.2$ & \\
\hline $\mathrm{P}+$ Lactose & $\mathrm{E}$ & $327.6 \pm 9.5$ & I & $110.4 \pm 4.9$ & I & $230.0 \pm 17.2$ & I \\
\hline & $\mathrm{F}$ & $236.4 \pm 9.4$ & & $50.0 \pm 5.0$ & & $159.5 \pm 12.5$ & \\
\hline $\mathrm{P}+$ Galactose & $\mathrm{E}$ & $275.9 \pm 7.7$ & $\mathrm{U}$ & $69.2 \pm 2.2$ & $\mathrm{U}$ & $168.4 \pm 16.1$ & $\mathrm{U}$ \\
\hline & $\mathrm{F}$ & $237.6 \pm 16.7$ & & $51.5 \pm 3.5$ & & $153.9 \pm 6.4$ & \\
\hline $\mathrm{P}+$ Fructose & $\mathrm{E}$ & $321.6 \pm 7.9$ & I & $100.1 \pm 9.7$ & I & $209.4 \pm 14.3$ & $\mathrm{U}$ \\
\hline & $\mathrm{F}$ & $266.3 \pm 3.9$ & & $44.2 \pm 3.8$ & & $175.2 \pm 8.0$ & \\
\hline $\mathrm{P}+$ Glucose & E & $289.3 \pm 7.4$ & $\mathrm{U}$ & $87.1 \pm 4.5$ & I & $179.1 \pm 15.7$ & $\mathrm{U}$ \\
\hline & $\mathrm{F}$ & $241.3 \pm 27.9$ & & $51.0 \pm 10.7$ & & $171.2 \pm 2.8$ & \\
\hline $\mathrm{P}+$ Pectin & $\mathrm{E}$ & $472.7 \pm 15.1$ & $\mathrm{P}$ & $91.5 \pm 5.9$ & I & $298.0 \pm 15.4$ & $\mathrm{U}$ \\
\hline & $\mathrm{F}$ & $538.1 \pm 4.6$ & & $54.7 \pm 1.7$ & & $319.7 \pm 58.5$ & \\
\hline $\mathrm{P}+$ Cellulose & $\mathrm{E}$ & $287.1 \pm 6.7$ & I & $90.8 \pm 58$ & I & $219.5 \pm 17.9$ & I \\
\hline & $\mathrm{F}$ & $193.0 \pm 10.9$ & & $66.3 \pm 5.8$ & & $159.4 \pm 2.7$ & \\
\hline $\mathrm{P}+$ Ascorbic acid & $\mathrm{E}$ & $29,375.5 \pm 34.2$ & $\mathrm{U}$ & $8663.0 \pm 370.0$ & I & $24,112.3 \pm 809.4$ & I \\
\hline & $\mathrm{F}$ & $29,213.6 \pm 29.2$ & & $6961.8 \pm 800.6$ & & $18,592.3 \pm 2269.0$ & \\
\hline P + Tocopherol & $\mathrm{E}$ & $296.7 \pm 9.9$ & I & $83.6 \pm 6.4$ & I & $187.3 \pm 17.2$ & I \\
\hline & $\mathrm{F}$ & $214.7 \pm 1.4$ & & $37.0 \pm 1.7$ & & $143.0 \pm 1.8$ & \\
\hline $\mathrm{P}+$ Citric acid & $\mathrm{E}$ & $283.7 \pm 6.9$ & I & $81.6 \pm 4.8$ & I & $170.9 \pm 15.7$ & I \\
\hline & $\mathrm{F}$ & $231.9 \pm 15.6$ & & $50.8 \pm 0.0$ & & $116.8 \pm 0.2$ & \\
\hline $\mathrm{P}+$ Salt & $\mathrm{E}$ & $255.5 \pm 8.3$ & I & $62.0 \pm 3.2$ & I & $177.6 \pm 12.1$ & I \\
\hline & $\mathrm{F}$ & $152.7 \pm 6.4$ & & $48.7 \pm 5.6$ & & $90.1 \pm 15.4$ & \\
\hline
\end{tabular}

* Values are means of triplicate measurements + standard deviations: The terms represent; TPC, total phenolic content; $\mathrm{P}$, pomegranate; PG, post gastric fraction (leaving the stomach); IN,

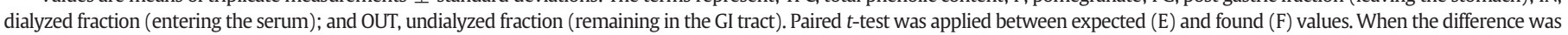
insignificant: $\mathrm{U}$-unaffected; when the difference was significant if $\mathrm{F}<\mathrm{E}$ : I-inhibiting effect, if $\mathrm{F}>\mathrm{E}$ : $\mathrm{P}-$ promoting effect. 
and Garcia-Viguera (2001) and Perez-Vicente et al. (2002) where they found cyn 3,5-di-O-glu and cyn-3-glu anthocyanins at the highest levels in pomegranate juice. In this research, cyanidin 3,5-0-diglucosides showed higher stability than their 3-0 glucoside structures as observed in other studies (Alighourchi, Bargezar, \& Abbasi, 2008; Marti et al., 2001). The higher stability of the diglucosides can be explained by the knowledge that glycosyl substitution at $\mathrm{C} 5$ reduces the nucleophilic character of the $\mathrm{C} 6$ and $\mathrm{C} 8$ positions; thus anthocyanin 3,5-diglucosides are less prone to electrophilic attack than 3-glucosides (Alighourchi et al., 2008; Marti et al., 2001; McDougall et al., 2005).

\subsection{Changes in total phenolic contents after codigesting pomegranate with other foodstuff or food components}

To understand the potential bioaccessibility of phenolic compounds in pomegranate after digestion with other foods and components, TPC values were measured and the data obtained is presented in Table 3. Expected (E) values were the theoretical sum of values obtained when each food or food component was consumed separately. Found (F) values were the exact values obtained when the pomegranate was consumed together with the foodstuff or the compound. In order to determine the changes in TPC of samples, expected and observed values were compared, statistically. If significant differences were obtained between the $\mathrm{E}$ and $\mathrm{F}$ values, in the case of decreasing effect it was denoted as Inhibiting effect-I or if just the opposite case as Promoting effect-P. If no significant change was observed than it was denoted as Unaffected $-\mathrm{U}$.

Generally consumption of pomegranate with foodstuffs or food components exerted either inhibiting effects or no effects on TPC value. Only for pectin at PG fraction a promoting effect on TPC was obtained. Oil, cream and galactose codigestion with pomegranate exerted no effect or possibly a protective effect on TPC at each fraction. On the other hand, milk, bread, yogurt, probiotic yogurt, starch, cooked starch, lactose, cellulose, tocopherol, citric acid and salt codigestion with pomegranate affected TPC content negatively at each fraction. The consumption of meat and bread with pomegranate caused significant reduction in PG and OUT as observed by McDougall et al. (2005) for raspberry.

Food matrices inhibiting TPC of pomegranate only at PG fraction were found to be lemon and soybean; for IN fraction only probiotic yogurt, apple, stearic acid, pectin and glucose were inhibitory and for the OUT fraction only meat was inhibitory. Food matrices having no significant effect in IN fraction but had inhibiting effects in both PG and OUT fractions were honey, soymilk, soy protein, casein and meat protein. On the other hand, matrices having no significant effect in OUT fraction but had inhibiting effects in both PG and IN fractions were linoleic acid and fructose. Ascorbic acid was the only one having no significant effect in PG fraction but had inhibiting effects in both IN and OUT fractions.

The preserving effect of oil on TPC content during digestion was observed in this study. According to Lesser, Cermak, and Wolfram (2004), oil addition to diet increased the bioavailability of quercetin and it was related to the delay in absorption and metabolism of oily foods that resulted in more quercetin absorption. Zhang et al. (2012) also found that milk fat did not interact with jujube juice phenolics. However, when jujube juice was ingested with whole milk, a significant reduction in the bioavailability of phenolics was reported and was related to the formation of complexes between proteins, fats, and phenolics during digestion. Some in vivo studies are available on the effect of oil or fats on the bioavailability of phenolic compounds (Lesser et al., 2004; Mullen et al., 2008; Zhang et al., 2012) but in vitro studies are very few (Ortega et al., 2009).

Significant decreases were evident for TPC of pomegranate $(p<0.05)$ when it was consumed with foods rich in protein content such as milk, bread, yogurt, soy protein, casein and meat protein especially for PG and OUT fractions. This inhibiting effect of proteins was not observed in IN fraction. Inhibiting effects in milk, yogurt and bread can be attributed to the effects of lactose and starch, respectively which caused inhibitions also in IN fractions. Langley-Evans (2000) observed the reducing effect of cow and soy milk when it was consumed with tea. Due to determination of the same effect for skimmed and semi skimmed milk, the reason of this effect was reported as protein content. Serafini et al. (2003) determined that absorption of flavonoids in chocolate decreased due to double bond formation between flavonoids and milk proteins.

The effect of milk and milk proteins on phenolics and antioxidant activity is a controversial topic. Keogh, Mclnerney, and Clifton (2007) found out that neither milk protein nor milk powder influences the average concentration of polyphenols in cocoa, while it slightly accelerated absorption. Alternatively some studies have shown that the addition of milk to tea inhibits its antioxidant activity whereas other workers have reported that the addition of milk does not alter the antioxidant activity of polyphenols in tea, coffee, or cocoa beverages (Richelle, Tavazzi, \& Offord, 2001; Serafini, Ghiselli, \& Ferro-Luzzi, 1996). Lower levels of plasma catechins have also been reported after drinking tea with milk compared to black tea (Reddy, Vidya Sagar, Sreeramulu, Venu, \& Raghunath, 2005). In contrast, other workers have reported that milk had no effect on plasma levels of catechins (Van het Hof, Kivits, Weststrate, \& Tijburg, 1998).

When the effects of carbohydrates were evaluated; starch, gelatinized starch, lactose and cellulose were found to adversely affect TPC content at each fraction, while lactose, fructose and glucose had adverse effects (about 2 fold decrease) in the IN fractions. Galactose seemed to preserve phenolics at each fraction of GI digestion. Although pectin was protective in PG and OUT fractions, the IN fraction had a 2fold decrease in TPC. Pectin has been shown to reduce bioavailability of $\beta$-carotenoid (Carlos, Ayala, \& Ganzalex-Aguilar, 2011).

Effects of salt or sugar were evaluated during dialysis by GilIzquierdo, Zafrilla, and Tomás-Barberán (2002) and the results were consistent with the ones found in this study. The phenolic content of the dialyzed fraction was considerably less with strawberry jams than with strawberries. This was explained by the higher sugar content of the jams which facilitated the diffusion of water from the dialysis tubing to the food phase.

\subsection{Changes in total anthocyanin contents after codigesting pomegranate with other foodstuff or food components}

Total anthocyanin content of pomegranate extract and combinations of pomegranate with other foods at each fraction of GI digestion were determined and compared statistically as shown in Fig. 1. As seen from the data, codigestion with common foodstuffs and components changed the bioaccessibility of anthocyanins in pomegranates. Total anthocyanins were found to be higher for each combination in PG fraction, followed by OUT and IN fractions, respectively. No difference was observed between pomegranate consumption alone and its codigestion with other foods during gastric conditions (PG) and for the fraction not absorbed in serum (OUT). However, there were significant reductions when pomegranate is codigested with meat, soy milk and cream for the fraction potentially absorbed in serum (IN).

In Fig. 2, TAC of pomegranate extract and combinations of pomegranate with other components at each fraction of GI digestion is given. According to the results, the order of decrease between the fractions for components was not similar to the order obtained for foodstuffs. When pomegranate is codigested with meat protein, stearic and linoleic acids, lactose, galactose fructose, starch and cellulose IN fractions were found to be higher than the values obtained for OUT. Even for stearic, linoleic acids, lactose and starch IN fraction was higher than both PG and OUT fractions.

After gastric conditions (PG) protein ingredients such as soy protein, casein, meat protein and gluten seemed to affect TAC content of pomegranate negatively, while ascorbic acid, fatty acids such as stearic acid and linoleic acid, and carbohydrates such as lactose, starch, cooked starch, pectin and cellulose had no significant effect on TAC contents. 


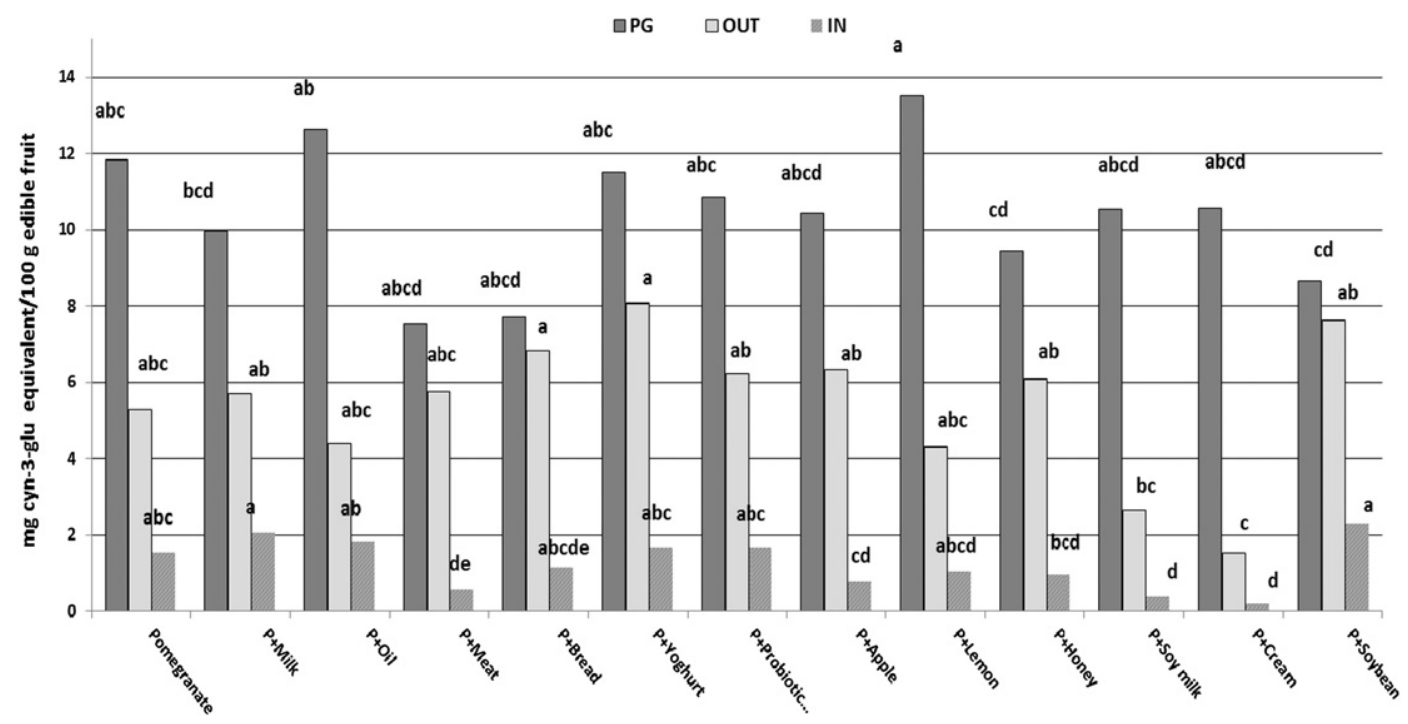

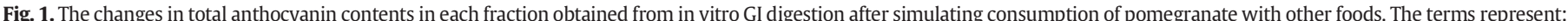

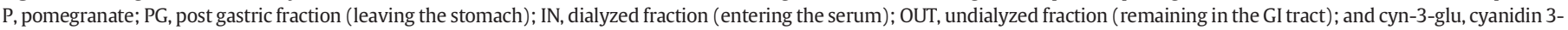
O-glucoside. Different letters for foodstuffs in the same series represent significant difference at $\mathrm{p}<0.05$.

However, galactose, fructose, glucose, tocopherol, citric acid and salt improved the TAC contents in PG fraction.

For OUT fractions meat protein was the only component affecting TAC negatively. On the other hand, other proteins such as soy protein, casein, and gluten had no significant effects similar to those like stearic acid, linoleic acid, lactose, galactose, fructose, starch and tocopherol. Glucose, pectin, cooked starch, cellulose, ascorbic acid, citric acid and salt showed promoting effect on TAC content in this fraction.

For the IN fraction which represents what enters into serum, food components fortunately either had no effects or positive effects on the TAC content of pomegranate. The ones having no effects were basically the protein components such as soy protein, casein, meat protein and gluten. However, all other components tested had positive effects on the bioaccessibility of pomegranate anthocyanins.

The cream contains milk fat, which in combination with protein and carbohydrates reduced its effects. In an in vivo study, when strawberries were consumed with cream, the peak plasma concentration of pel 3-O- glu was not different than when strawberries are consumed alone. The only difference was the delay in peak plasma concentration indicating that cream delayed gastric emptying and extended mouth to cecum transit time. However the results obtained in this study for the decreasing effect of cream in IN fraction are taking into account all the anthocyanins available in pomegranate instead of just the pel-3-O-glu (Mullen et al., 2008).

McDougall et al. (2005) found that raspberry anthocyanins in IN fractions were either unaffected (breakfast cereal and ice cream) or increased (cooked minced beef) during codigestion with other foodstuffs. In this study minced meat, soymilk and cream were found to decrease anthocyanins in the IN fraction.

Another study by Walton, Hendriks, Broomfield, and McGhie (2009) evaluated the effect of viscous food matrix effect on blackcurrant anthocyanins in vivo. Rats were fed with blackcurrant and its codigestion with oatmeal was investigated. It was reported that simultaneous intake of oatmeal affected anthocyanin absorption and urinary excretion.

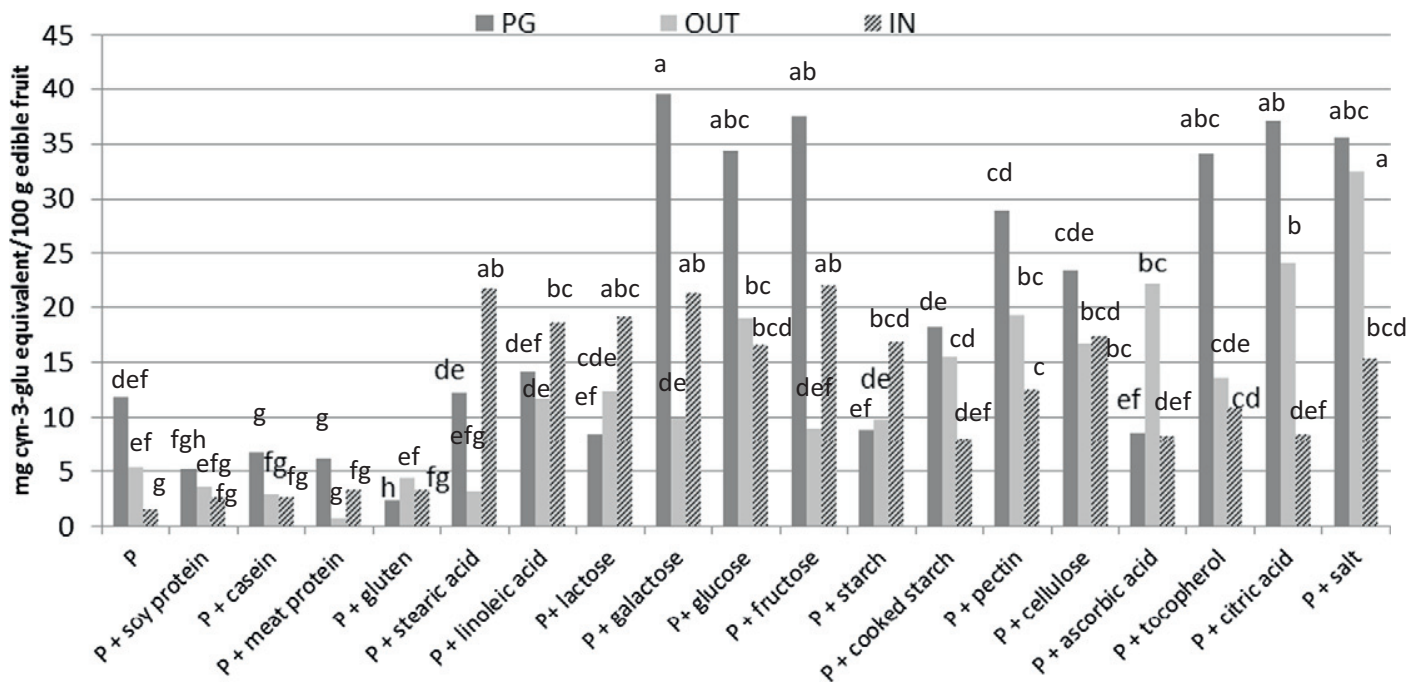

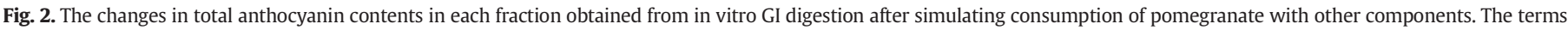


glu, cyanidin 3-O-glucoside. Different letters for food components in the same series represent significant difference at $\mathrm{p}<0.05$. 
Table 4

Changes in major anthocyanin contents ( $\mathrm{mg} / 100 \mathrm{~g}$ edible fruit) of pomegranate after codigesting with other foods.

\begin{tabular}{|c|c|c|c|c|c|c|}
\hline Samples & & Del 3,5-di-O-glu & Cyn 3,5-di-O-glu & Pel 3,5-di-O-glu & Cyn-3-glu & Pel 3-O-glu \\
\hline \multirow[t]{3}{*}{ Pomegranate control } & PG & $7.9 \pm 1.8^{\mathrm{a}}$ & $11.2 \pm 2.2^{\mathrm{ab}}$ & $17.9 \pm 7.9^{\mathrm{ab}}$ & $4.7 \pm 0.0^{\mathrm{ab}}$ & $0.5 \pm 0.1^{\mathrm{a}}$ \\
\hline & OUT & $\mathrm{ND}$ & $2.3 \pm 1.7^{\text {cde }}$ & ND & $0.2 \pm 0.0^{\mathrm{b}}$ & ND \\
\hline & IN & ND & $0.9 \pm 0.6^{\mathrm{abc}}$ & ND & $0.1 \pm 0.0^{\mathrm{a}}$ & ND \\
\hline \multirow[t]{3}{*}{$P+$ Oil } & PG & $5.6 \pm 1.4^{\mathrm{ab}}$ & $12.0 \pm 0.8^{\mathrm{a}}$ & $19.7 \pm 8.3^{\mathrm{ab}}$ & $5.1 \pm 0.6^{\mathrm{a}}$ & $0.5 \pm 0.1^{\mathrm{a}}$ \\
\hline & OUT & ND & $4.6 \pm 0.2^{\mathrm{bcd}}$ & $4.6 \pm 0.1^{\mathrm{a}}$ & $1.3 \pm 0.8^{\mathrm{a}}$ & ND \\
\hline & IN & ND & $0.7 \pm 0.1^{\mathrm{bc}}$ & $0.1 \pm 0.0$ & ND & ND \\
\hline \multirow[t]{3}{*}{$\mathrm{P}+$ Milk } & PG & $6.4 \pm 1.1^{\mathrm{ab}}$ & $9.0 \pm 1.5^{\mathrm{abcd}}$ & $15.0 \pm 4.7^{\mathrm{ab}}$ & $4.1 \pm 0.0^{\mathrm{abc}}$ & $0.2 \pm 0.0^{c}$ \\
\hline & OUT & ND & $8.8 \pm 0.2^{\mathrm{b}}$ & ND & $0.8 \pm 0.1^{\mathrm{ab}}$ & ND \\
\hline & IN & ND & $1.5 \pm 0.4^{\mathrm{a}}$ & ND & $0.2 \pm 0.1^{\mathrm{a}}$ & ND \\
\hline \multirow{3}{*}{$P+$ Meat } & PG & $5.0 \pm 1.1^{\mathrm{ab}}$ & $6.4 \pm 0.3^{\mathrm{d}}$ & $8.1 \pm 2.5^{\mathrm{b}}$ & $1.8 \pm 0.2^{\mathrm{e}}$ & $0.2 \pm 0.0^{c}$ \\
\hline & OUT & ND & $4.4 \pm 1.3^{\mathrm{bcd}}$ & ND & $0.5 \pm 0.2^{\mathrm{ab}}$ & ND \\
\hline & IN & ND & $0.5 \pm 0.4^{\mathrm{bc}}$ & ND & $0.1 \pm 0.1^{\mathrm{a}}$ & ND \\
\hline \multirow{3}{*}{$\mathrm{P}+$ Bread } & PG & $5.6 \pm 1.4^{\mathrm{ab}}$ & $7.7 \pm 0.6^{\mathrm{cd}}$ & $8.7 \pm 3.5^{\mathrm{ab}}$ & $2.6 \pm 0.2^{\text {cde }}$ & $0.2 \pm 0.0^{c}$ \\
\hline & OUT & ND & $10.5 \pm 3.0^{\mathrm{ab}}$ & ND & $1.3 \pm 0.8^{\mathrm{a}}$ & $0.3 \pm 0.0$ \\
\hline & IN & ND & $0.9 \pm 0.1^{\mathrm{abc}}$ & ND & $0.1 \pm 0.0^{\mathrm{a}}$ & ND \\
\hline \multirow{3}{*}{$\mathrm{P}+$ Yogurt } & PG & $6.5 \pm 1.0^{\mathrm{ab}}$ & $7.0 \pm 0.7^{\mathrm{d}}$ & $18.0 \pm 5.2^{\mathrm{ab}}$ & $2.0 \pm 2.6^{\mathrm{de}}$ & $0.2 \pm 0.0^{c}$ \\
\hline & OUT & ND & $5.1 \pm 1.1^{\mathrm{bc}}$ & ND & $0.9 \pm 0.1^{\mathrm{ab}}$ & ND \\
\hline & IN & ND & $1.5 \pm 0.4^{\mathrm{a}}$ & ND & $0.2 \pm 0.0^{\mathrm{a}}$ & ND \\
\hline \multirow{3}{*}{$\mathrm{P}+$ Probiotic } & PG & $4.7 \pm 0.8^{\mathrm{b}}$ & $8.7 \pm 0.9^{\mathrm{bcd}}$ & $12.2 \pm 1.0^{\mathrm{ab}}$ & $3.7 \pm 0.4^{\mathrm{abcd}}$ & $0.3 \pm 0.1^{\mathrm{bc}}$ \\
\hline & OUT & ND & $7.1 \pm 1.9^{\mathrm{b}}$ & $1.1 \pm 0.3^{\mathrm{b}}$ & $1.0 \pm 0.2^{\mathrm{ab}}$ & ND \\
\hline & IN & ND & $1.3 \pm 0.5^{\mathrm{ab}}$ & ND & $0.1 \pm 0.0^{\mathrm{a}}$ & ND \\
\hline \multirow[t]{3}{*}{$\mathrm{P}+$ Apple } & PG & $5.9 \pm 1.6^{\mathrm{ab}}$ & $8.7 \pm 1.5^{\mathrm{bcd}}$ & $13.2 \pm 6.1^{\mathrm{ab}}$ & $3.8 \pm 0.2^{\mathrm{abcd}}$ & $0.3 \pm 0.0^{\mathrm{bc}}$ \\
\hline & OUT & ND & $0.4 \pm 0.1^{\mathrm{e}}$ & ND & $0.3 \pm 0.1^{\mathrm{b}}$ & ND \\
\hline & IN & ND & $0.2 \pm 0.1^{\mathrm{c}}$ & ND & $0.1 \pm 0.1^{\mathrm{a}}$ & ND \\
\hline \multirow[t]{3}{*}{$\mathrm{P}+$ Lemon } & PG & $8.6 \pm 0.1^{\mathrm{a}}$ & $9.4 \pm 0.4^{\mathrm{abcd}}$ & $21.8 \pm 0.4^{\mathrm{a}}$ & $4.7 \pm 0.1^{\mathrm{a}}$ & $0.3 \pm 0.1^{b c}$ \\
\hline & OUT & ND & $1.4 \pm 0.9^{\text {de }}$ & ND & $0.3 \pm 0.1^{\mathrm{b}}$ & ND \\
\hline & IN & ND & $0.2 \pm 0.0^{c}$ & ND & ND & $0.1 \pm 0.0$ \\
\hline \multirow[t]{3}{*}{$\mathrm{P}+$ Honey } & PG & $5.9 \pm 1.7^{\mathrm{ab}}$ & $8.8 \pm 1.5^{\mathrm{bcd}}$ & $15.2 \pm 6.9^{\mathrm{ab}}$ & $4.0 \pm 0.1^{\mathrm{abc}}$ & ND \\
\hline & OUT & ND & $3.4 \pm 1.0^{\text {cde }}$ & ND & $0.2 \pm 0.1^{\mathrm{b}}$ & ND \\
\hline & IN & ND & $0.4 \pm 0.1^{\mathrm{bc}}$ & ND & ND & ND \\
\hline \multirow[t]{3}{*}{$\mathrm{P}+$ Soy milk } & PG & $6.3 \pm 1.4^{\mathrm{ab}}$ & $10.3 \pm 2.0^{\mathrm{ab}}$ & $14.7 \pm 4.9^{\mathrm{ab}}$ & $4.3 \pm 0.0^{\mathrm{abc}}$ & $0.3 \pm 0.0^{\mathrm{bc}}$ \\
\hline & OUT & ND & $0.4 \pm 0.1^{\mathrm{e}}$ & ND & ND & ND \\
\hline & IN & ND & ND & ND & ND & ND \\
\hline \multirow[t]{3}{*}{$\mathrm{P}+$ Cream } & PG & $5.2 \pm 1.0^{\mathrm{ab}}$ & $7.5 \pm 1.4^{\mathrm{cd}}$ & $11.4 \pm 4.0^{\mathrm{ab}}$ & $3.4 \pm 0.0^{\mathrm{abcde}}$ & $0.3 \pm 0.0^{\mathrm{bc}}$ \\
\hline & OUT & ND & $1.2 \pm 0.4^{\mathrm{de}}$ & ND & ND & ND \\
\hline & IN & ND & ND & ND & ND & ND \\
\hline \multirow[t]{3}{*}{$\mathrm{P}+$ Soybean } & PG & $5.4 \pm 2.3^{\mathrm{ab}}$ & $8.1 \pm 0.4^{\mathrm{bcd}}$ & $8.5 \pm 5.0^{\mathrm{ab}}$ & $2.8 \pm 0.2^{\text {cde }}$ & $0.4 \pm 0.2^{\mathrm{ab}}$ \\
\hline & OUT & ND & $3.5 \pm 0.6^{\text {bcde }}$ & ND & $0.5 \pm .19^{\mathrm{ab}}$ & ND \\
\hline & IN & ND & $1.1 \pm 0.5^{\mathrm{abc}}$ & ND & $0.2 \pm 0.0^{\mathrm{a}}$ & ND \\
\hline
\end{tabular}

* Values are means of triplicate measurements \pm standard deviations. Different letters in the same column present significant difference at $\mathrm{p}<0.05$. The terms represent; PG, post gastric

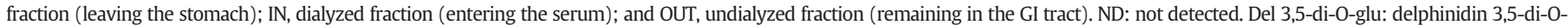

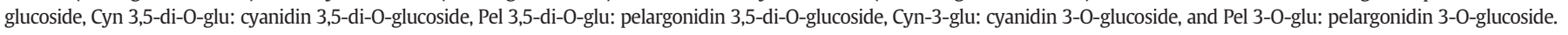

Anthocyanins were absorbed and excreted faster, when administered in an acidified water solution than in an acidified oatmeal solution. In this study, pectin and cooked starch as viscous food matrices increased anthocyanins in both OUT and IN fractions.

\subsection{Changes in major anthocyanins and punicalagin after codigesting pomegranate with other foodstuff or food components}

The changes in major anthocyanins after consumption of pomegranate with other foods and food components were evaluated as shown in Tables 4 and 5, respectively. Del 3,5-di-O-glu was not detected in IN and OUT fractions; and there was no significant difference between control and pomegranate codigested with other foods in PG fraction, except for probiotic yogurt which resulted in significant reduction $(p<0.05)$. For cyn 3,5-di-O-glu in PG fraction, meat, bread, yogurt and cream codigestion with pomegranate resulted in significant losses. However for other foods no effect was evident. When OUT fraction was evaluated for the same anthocyanin, milk, bread and probiotic yogurt seemed to increase the amount of that compound. In IN fraction cyn 3,5-di-O-glu was lost when pomegranate was codigested with soymilk and cream. Pel 3,5-di-O-glu of pomegranate could not be determined after pancreatic digestion (IN and OUT) except for oil and probiotic yogurt codigestion. After gastric digestion (PG) no significant difference was observed for codigestion of pomegranate with other foods ( $p$ $>0.05$ ), however the only reduction was for meat codigestion with pomegranate $(\mathrm{p}<0.05)$. Digestion of pomegranate with meat, bread, soybean and yogurt inhibited potential bioaccessibility of cyn-3-glu during gastric conditions while the other foods preserved its content. On the other hand, for OUT fraction, there was a synergistic effect of consuming pomegranate with oil or bread, while an antagonistic effect was obvious when it is codigested with soymilk or cream. For IN fraction, cyn-3-glu disappeared from oil, lemon, honey, soymilk and cream; however, for other foods the level of cyn-3-glu was preserved. Cyanidins were determined to be more stable to food matrices and pancreatic conditions than other anthocyanins. Pel 3-O-glu could not be detected after pancreatic digestion and for gastric digestion, oil and soybean exerted no effect, while all other foods had negative effects on this anthocyanin.

From Table 5 it can be seen that, similar to the results obtained for codigestion with foodstuffs, codigestion with food components caused del-3,5-di-O-glu, pel 3,5-di-O-glu and cyn-3-glu anthocyanins to be lost in most IN and OUT fractions. But for citric acid codigestion with pomegranate, there was no change in PG, and in the IN and OUT fractions all major anthocyanins were available. With ascorbic acid, anthocyanins in PG fraction were lost whereas in the OUT fraction they were present. When the effect of proteins was evaluated, generally they made no significant effect on pomegranate major anthocyanins at each fraction they were detected in. Only casein codigestion seemed to have a positive effect on cyn 3,5-di-O-glu levels in OUT fraction similar to the result obtained for milk. 
Table 5

Changes in major anthocyanin contents ( $\mathrm{mg} / 100 \mathrm{~g}$ edible fruit) of pomegranate after codigesting with food components.

\begin{tabular}{|c|c|c|c|c|c|}
\hline Samples & & Del 3,5-di-O-glu & Cyn 3,5-di-O-glu & Pel 3,5-di-O-glu & Cyn-3-glu \\
\hline \multirow[t]{3}{*}{ Pomegranate control } & PG & $7.9 \pm 1.8^{b}$ & $11.22 .2^{\mathrm{b}}$ & $17.9 \pm 7.9^{\mathrm{ab}}$ & $4.7 \pm 0.0^{\text {cd }}$ \\
\hline & OUT & ND & $2.3 \pm 1.7^{\text {cde }}$ & ND & $0.2 \pm 0.0^{\mathrm{b}}$ \\
\hline & IN & ND & $0.9 \pm 0.6^{c}$ & ND & $0.1 \pm 0.0^{c}$ \\
\hline \multirow[t]{3}{*}{$\mathrm{P}+$ Soy protein } & PG & $6.9 \pm 0.6^{\mathrm{b}}$ & $9.3 \pm 2.9^{b}$ & $7.1 \pm 2.5^{\mathrm{ab}}$ & $4.0 \pm 1.8^{\mathrm{de}}$ \\
\hline & OUT & ND & $7.4 \pm 0.1^{\mathrm{abcd}}$ & $9.5 \pm 1.1^{\mathrm{b}}$ & $1.7 \pm 0.6^{\mathrm{b}}$ \\
\hline & IN & ND & $1.9 \pm 0.1^{\mathrm{bc}}$ & ND & ND \\
\hline \multirow[t]{3}{*}{$\mathrm{P}+$ Casein } & PG & $9.2 \pm 1.9^{\mathrm{ab}}$ & $9.6 \pm 1.4^{\mathrm{b}}$ & $20.6 \pm 0.3^{\mathrm{a}}$ & $5.2 \pm 0.2^{\mathrm{bcd}}$ \\
\hline & OUT & ND & $9.3 \pm 0.2^{\mathrm{ab}}$ & ND & $2.1 \pm 0.7^{\mathrm{b}}$ \\
\hline & IN & ND & $1.6 \pm 0.1^{\mathrm{bc}}$ & ND & ND \\
\hline \multirow[t]{3}{*}{$\mathrm{P}+$ Meat protein } & PG & $9.4 \pm 4.5^{\mathrm{ab}}$ & $12.4 \pm 0.6^{\mathrm{ab}}$ & $15.3 \pm 6.7^{\mathrm{ab}}$ & $4.5 \pm 0.7^{\mathrm{cd}}$ \\
\hline & OUT & ND & $4.4 \pm 2.3^{\mathrm{bcd}}$ & ND & $0.5 \pm 0.1^{\mathrm{b}}$ \\
\hline & IN & ND & $2.6 \pm 0.8^{\mathrm{ab}}$ & ND & $0.5 \pm 0.2^{\mathrm{bc}}$ \\
\hline \multirow{3}{*}{$\mathrm{P}+$ Gluten } & PG & $6.6 \pm 1.8^{\mathrm{b}}$ & $11.5 \pm 0.4^{\mathrm{b}}$ & $10.4 \pm 3.0^{\mathrm{ab}}$ & $3.6 \pm 0.3^{\text {de }}$ \\
\hline & OUT & ND & $6.1 \pm 2.8^{\mathrm{abcd}}$ & ND & $0.6 \pm 0.1^{\mathrm{b}}$ \\
\hline & IN & ND & $1.5 \pm 0.7^{\mathrm{bc}}$ & ND & ND \\
\hline \multirow{3}{*}{ P + Stearic acid } & PG & $7.9 \pm 1.5^{\mathrm{b}}$ & $13.5 \pm 1.4^{\mathrm{ab}}$ & $17.9 \pm 6.5^{\mathrm{ab}}$ & $5.6 \pm 0.5^{\mathrm{bcd}}$ \\
\hline & OUT & ND & $3.5 \pm 1.1^{\mathrm{bcd}}$ & ND & $0.5 \pm 0.2^{\mathrm{b}}$ \\
\hline & IN & ND & $1.4 \pm 0.2^{\mathrm{bc}}$ & ND & $\mathrm{ND}$ \\
\hline \multirow[t]{3}{*}{$\mathrm{P}+$ Linoleic acid } & PG & $8.5 \pm 0.5^{\mathrm{ab}}$ & $13.8 \pm 3.1^{\mathrm{ab}}$ & $16.5 \pm 0.3^{\mathrm{ab}}$ & $5.3 \pm 0.7^{\mathrm{bcd}}$ \\
\hline & OUT & ND & $0.8 \pm 1.1^{\mathrm{cd}}$ & ND & $0.3 \pm 0.0^{\mathrm{b}}$ \\
\hline & IN & ND & ND & ND & $\mathrm{ND}$ \\
\hline \multirow{3}{*}{$\mathrm{P}+$ Starch } & PG & $7.6 \pm 4.0^{\mathrm{b}}$ & $12.5 \pm 0.0^{\mathrm{ab}}$ & $15.1 \pm 6.6^{\mathrm{ab}}$ & $5.2 \pm 0.2^{\mathrm{bcd}}$ \\
\hline & OUT & ND & $6.7 \pm 0.9^{\mathrm{abcd}}$ & ND & ND \\
\hline & IN & ND & ND & ND & ND \\
\hline \multirow[t]{3}{*}{$\mathrm{P}+$ Cooked starch } & PG & $1.3 \pm 0.8^{c}$ & $1.4 \pm 0.2^{\mathrm{c}}$ & $1.9 \pm 0.7^{\mathrm{b}}$ & $0.7 \pm 0.1^{\mathrm{f}}$ \\
\hline & OUT & ND & $1.2 \pm 0.0^{\mathrm{d}}$ & ND & ND \\
\hline & IN & ND & $0.7 \pm 0.4^{\mathrm{c}}$ & ND & ND \\
\hline \multirow[t]{3}{*}{$\mathrm{P}+$ Lactose } & PG & $7.9 \pm 0.6^{\mathrm{b}}$ & $11.7 \pm 2.6^{\mathrm{ab}}$ & $17.7 \pm 8.3^{\mathrm{ab}}$ & $5.5 \pm 0.3^{\mathrm{bcd}}$ \\
\hline & OUT & ND & $3.9 \pm 0.5^{\mathrm{bcd}}$ & ND & $0.6 \pm 0.1^{\mathrm{b}}$ \\
\hline & IN & ND & $1.3 \pm 0.2^{\mathrm{bc}}$ & ND & ND \\
\hline \multirow[t]{3}{*}{$\mathrm{P}+$ Galactose } & PG & $9.3 \pm 2.0^{\mathrm{ab}}$ & $14.6 \pm 3.1^{\mathrm{a}}$ & $22.2 \pm 5.2^{\mathrm{a}}$ & $6.3 \pm 0.4^{\mathrm{a}}$ \\
\hline & OUT & ND & $10.0 \pm 7.6^{\mathrm{ab}}$ & ND & $0.9 \pm 0.2^{\mathrm{b}}$ \\
\hline & IN & ND & $1.6 \pm 0.3^{\mathrm{bc}}$ & ND & ND \\
\hline \multirow[t]{3}{*}{$\mathrm{P}+$ Fructose } & PG & $11.4 \pm 2.3^{\mathrm{a}}$ & $15.9 \pm 4.2^{\mathrm{a}}$ & $23.3 \pm 6.5^{\mathrm{a}}$ & $6.4 \pm 0.5^{\mathrm{a}}$ \\
\hline & OUT & ND & $14.2 \pm 1.2^{\mathrm{a}}$ & ND & $1.3 \pm 0.3^{\mathrm{ab}}$ \\
\hline & IN & ND & $2.5 \pm 1.1^{\mathrm{ab}}$ & ND & ND \\
\hline \multirow[t]{3}{*}{$\mathrm{P}+$ Glucose } & PG & $10.1 \pm 5.5^{\mathrm{a}}$ & $13.7 \pm 0.6^{\mathrm{ab}}$ & $21.1 \pm 9.4^{\mathrm{a}}$ & $6.1 \pm 1.2^{\mathrm{ab}}$ \\
\hline & OUT & ND & $6.8 \pm 1.0^{\mathrm{abcd}}$ & ND & ND \\
\hline & IN & ND & $2.2 \pm 0.1^{\mathrm{b}}$ & ND & ND \\
\hline \multirow[t]{3}{*}{$\mathrm{P}+$ Pectin } & PG & ND & ND & ND & ND \\
\hline & OUT & ND & ND & ND & ND \\
\hline & IN & ND & $0.3 \pm 0.1^{\mathrm{c}}$ & ND & ND \\
\hline \multirow[t]{3}{*}{$\mathrm{P}+$ Cellulose } & PG & $7.8 \pm 1.8^{\mathrm{b}}$ & $14.2 \pm 2.8^{\mathrm{ab}}$ & $7.9 \pm 3.3^{\mathrm{ab}}$ & $3.9 \pm 0.4^{\mathrm{de}}$ \\
\hline & OUT & ND & $4.5 \pm 0.3^{\mathrm{bcd}}$ & ND & ND \\
\hline & IN & ND & $0.9 \pm 0.1^{\mathrm{abc}}$ & ND & ND \\
\hline \multirow[t]{3}{*}{$\mathrm{P}+$ Ascorbic acid } & PG & ND & ND & ND & $0.1 \pm 0.0^{f}$ \\
\hline & OUT & $1.7 \pm 0.6^{\mathrm{b}}$ & $1.5 \pm 0.9^{d}$ & $0.7 \pm 0.2^{\mathrm{c}}$ & $0.2 \pm 0.0^{\mathrm{b}}$ \\
\hline & IN & ND & $0.1 \pm 0.0^{c}$ & ND & $0.2 \pm 0.1^{\mathrm{c}}$ \\
\hline \multirow[t]{3}{*}{ P + Tocopherol } & PG & $10.3 \pm 3.8^{\mathrm{a}}$ & $12.5 \pm 0.4^{\mathrm{ab}}$ & $18.4 \pm 10.8^{\mathrm{ab}}$ & $5.3 \pm 1.1^{\mathrm{bcd}}$ \\
\hline & OUT & ND & $4.4 \pm 3.0^{\mathrm{bcd}}$ & ND & ND \\
\hline & IN & ND & ND & ND & ND \\
\hline $\mathrm{P}+$ Citric acid & PG & $10.0 \pm 1.6^{\mathrm{a}}$ & $13.8 \pm 4.6^{\mathrm{ab}}$ & $21.9 \pm 11.1^{\mathrm{a}}$ & $6.7 \pm 0.2^{\mathrm{a}}$ \\
\hline & OUT & $12.4 \pm 2.6^{\mathrm{a}}$ & $12.0 \pm 2.7^{\mathrm{a}}$ & $23.4 \pm 3.9^{\mathrm{a}}$ & $5.5 \pm 1.3^{\mathrm{a}}$ \\
\hline & IN & $2.7 \pm 0.7$ & $3.7 \pm 0.4^{\mathrm{a}}$ & $6.4 \pm 0.0$ & $1.9 \pm 0.2^{\mathrm{a}}$ \\
\hline $\mathrm{P}+$ Salt & PG & $11.9 \pm 3.2^{\mathrm{a}}$ & $11.9 \pm 1.1^{\mathrm{ab}}$ & $20.0 \pm 10.3^{\mathrm{a}}$ & $5.3 \pm 0.3^{\mathrm{bcd}}$ \\
\hline & OUT & ND & $8.0 \pm 3.5^{\mathrm{abc}}$ & ND & $1.4 \pm 0.9^{\mathrm{b}}$ \\
\hline & IN & ND & $2.9 \pm 0.2^{\mathrm{ab}}$ & ND & $0.8 \pm 0.2^{\mathrm{b}}$ \\
\hline
\end{tabular}

* Values are mean of triplicate measurements \pm standard deviations. Different letters in the same column present significant difference at $\mathrm{p}<0.05$. The terms represent; P, pomegranate. PG,

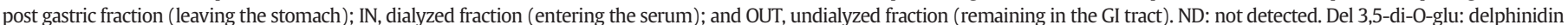

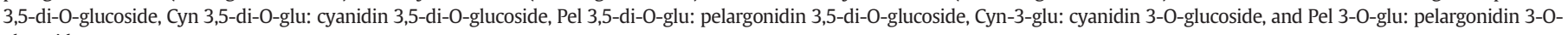
glucoside.

Fatty acids had no significant effects on major anthocyanin contents at each fraction $(p>0.05)$. On the other hand tocopherol and salt had positive effects on del 3,5-di-O-glu contents in PG fraction. Besides, salt had positive effect on cyn 3-O-glu level in IN fraction. For the effects of carbohydrates, it can be said that after gastric digestion (PG) cooked starch was the only one having negative effects on del 3,5-di-O-glu, cyn 3,5-di-O-glu and cyn-3-glu levels. On the other hand, fructose and glucose increased the levels of del 3,5-di-O-glu and cyn-3-glu, whereas galactose and fructose increased the level of cyn 3,5-di-O-glu significantly $(p<0.05)$ in the same fraction. For OUT fraction both galactose and fructose and for IN fraction only fructose increased cyn 3,5-diO-glu level significantly.

Study of Toydemir et al. (2013) about the transport of anthocyanins from sour cherry across the intestinal epithelial barrier was in agreement with the findings for citric acid and sugars in this study. The juice supplements, sucrose and citric acid, were found to have positive effects on stability and transport. Higher transport efficiency was obtained in fruit or juice with respect to pure anthocyanin extracts, 
indicating the importance of food matrix components for intestinal absorption of polyphenols (Toydemir et al., 2013).

When the effects of codigestion with foodstuffs and food components on the major phenolic punicalagin were evaluated (data not shown), bread, yogurt, honey, cream, soybean, gluten, starch, cooked starch and salt were found to negatively affect the content of punicalagin in the IN fraction. On the other hand, meat, all sugars, pectin, cellulose, soy protein, meat protein, fatty acids and citric acid had positive effects on the level of punicalagin. For OUT fraction apple, cream and soybean decreased whereas oil, milk, meat, probiotic yogurt and starch increased the level of major phenolics. For post gastric fraction none of the codigested foods had positive effects, while milk, meat, bread, yogurt, probiotic yogurt, honey, cream, soybean, salt and tocopherol all had negative effects on the punicalagin concentration.

Enhancement of the digestibility of phenolic compounds in carob flour was evident in the presence of hazelnut oil rich in monounsaturated fatty acids (Ortega et al., 2009) similar to the positive effects of stearic acid and linoleic acid on punicalagin in this study.

While evaluating the results obtained for anthocyanin and phenolic profiles only the concentrations of initial anthocyanins were evaluated, meaning that if any new compound or metabolite is formed or if any conversion occurs during GI digestion it was neglected. A recent study by Liang et al. (2012) has shown that the major anthocyanins in mulberry, cyanidin-3-glucoside and cyaniding-3-rutinoside, were greatly reduced after digestion and even disappeared after pancreatic digestion. Apart from cyanidin aglycon, 18 phenolic metabolites were characterized consisting of phenolic acids, flavonoids and their derivatives.

\section{Conclusions}

Phenolic compounds of pomegranate were found to be more stable to gastrointestinal digestion than anthocyanins. Losses were mostly during pancreatic digestion rather than gastric digestion. Anthocyanins were generally stable during gastric digestion however during pancreatic digestion only cyn 3,5 di-O-glu and cyn 3-O-glu were stable to a limited degree. For total phenolic content values, milk, bread, yogurt, probiotic yogurt, lactose, starch, cellulose, salt, citric acid or tocopherol decreased TPC at all fractions. Proteins were most effective in increasing the losses in the PG and OUT fractions. Instead of proteins, carbohydrates such as starch, lactose, glucose and pectin seem to be effective components for increasing the loss of phenolics exerting 2-fold decreases in the serum fraction (IN). On the other hand, for total anthocyanin contents meat, soymilk or cream codigestion with pomegranate resulted in losses only in serum fraction (IN). Most carbohydrates and fatty acids increased TAC in the same fraction even greater than that in the OUT fraction. Proteins were not significantly effective in decreasing TAC in the IN fraction however they were effective in increasing losses during gastric digestion (PG).

Overall it can be said that food components or food matrices have different effects on anthocyanins and other phenolic compounds. While developing or consuming a functional food product, the interaction of the bioactive compound with a food component in a food matrix should be considered to increase the bioaccessibility of that compound. Future studies should focus on the conversions between those polyphenolic compounds and the metabolites formed to better understand the fate of polyphenols during digestion.

\section{Acknowledgments}

This study was supported by EU 7th Framework Project ATHENA (Anthocyanin and Polyphenol Bioactives for Health Enhancement through Nutritional Advancement), Istanbul Technical University (ITU), Scientific Research and Development Support Project titled "Investigating the effect of food matrix and components on anthocyanin bioavailability" and Istanbul Technical University (ITU) Institute of Science, Engineering and Technology Graduate study support fund.

\section{References}

Alighourchi, H., Bargezar, M., \& Abbasi, S. (2008). Anthocyanins characterization of 15 Iranian pomegranate (Punica granatum L.) varieties and their variation after cold storage and pasteurization. European Food Research and Technology, 227, 881-887.

Bino, R. J., Vos, C. H. R. D., Lieberman, M., Hall, R. D., Bovy, A., Jonker, H. H., et al. (2005). The light hyperresponsive high pigment-2 mutation of tomato: Alterations in the fruit metabolome. New Phytologist, 166, 427-438.

Carlos, H. P., Ayala, J. F., \& Ganzalex-Aguilar, A. G. (2011). The role of dietary fiber in the bioaccessibility and bioavailability. Journal of Food Science, 76, R6-R15.

Cebeci, F., \& Sahin-Yesilcubuk, N. (2014). The matrix effect of blueberry, oat meal and milk on polyphenols, antioxidant activity and potential bioavailability. International Journal of Food Sciences and Nutrition, 65, 69-78.

Dupas, C. J., Marsset-Baglieri, C. J., Ordonaud, C. S., Ducept, F. M. G., \& Maillard, M. N. (2006). Coffee antioxidant properties: Effects of milk addition and processing conditions. Journal of Food Science, 71, 253-258.

Fazzari, M., Fukumoto, L., Mazza, G., Livrea, M.A., Tesoriere, L., \& Marco, L. D. (2008). In vitro bioavailability of phenolic compounds from five cultivars of frozen sweet cherries (Prunus avium L.). Journal of Agricultural and Food Chemistry, 56, 3561-3568.

Gil-Izquierdo, M., Tomas-Barberan, F. A., Hess-Pierce, B., Holcroft, D.M., \& Kader, A. A (2000). Antioxidant activity of pomegranate juice and its relationship with phenolic composition and processing. Journal of Agricultural and Food Chemistry, 48, 4581-4589.

Gil-Izquierdo, A., Zafrilla, P., \& Tomás-Barberán, F. A. (2002). An in vitro method to simulate phenolic compound release from the food matrix in the gastrointestinal tract. European Food Research and Technology, 214, 155-159.

Hernandez, F., Melgarejo, P., Tomas-Barberon, F. A., \& Artes, F. (1999). Evolution of juice anthocyanins during ripening of new selected pomegranate (Punica granatum) clones. European Food Research and Technology, 210, 39-42.

Hur, S. J., Lim, B. O., Decker, E. A., \& McClements, D. J. (2011). In vitro human digestion models for food applications. Food Chemistry, 125, 1-12.

Kar, C. E., Ferchichi, A., Attia, F., \& Bouajila, J. (2011). Pomegranate (Punica granatum) juices: Chemical composition, micronutrient cations and antioxidant capacity. Journal of Food Science, 76, 795-800.

Karadeniz, F., Burdurlu, H. S., Koca, N., \& Soyer, Y. (2005). Activity of selected fruits and vegetables grown in Turkey. Tubitak Journal of Agricultural and Forestry, 29, 297-303.

Keogh, J. B., Mclnerney, J., \& Clifton, P.M. (2007). The effect of milk protein on the bioavailability of cocoa polyphenols. Journal of Food Science, 72, 230-233.

Langley-Evans, S.C. (2000). Consumption of black tea elicits an increase in plasma antioxidant potential in humans. International Journal of Food Science and Nutrition, 51, 309-315.

Larkin, T. A., Price, W. E., \& Astheimer, L. B. (2007). Increased probiotic yogurt or resistant starch intake does not affect isoflavone bioavailability in subjects consuming a high soy diet. Nutrition, 23, 709-718.

Lesser, S., Cermak, R., \& Wolfram, S. (2004). Bioavailability of quercetin in pigs is influenced by the dietary fat content. The Journal of Nutrition, 134, 1508-1511.

Liang, L., Wu, X., Zhao, T., Zhao, J., Li, F., Zou, Y., et al. (2012). In vitro bioaccessibility and antioxidant activity of anthocyanins from mulberry (Morus atropurpurea Roxb.) following simulated gastro-intestinal digestion. Food Research International, 46, $176-182$.

Marti, N., Perez-Vicente, A., \& Garcia-Viguera, C. (2001). Influence of storage temperature and ascorbic acid addition on pomegranate juice. Journal of the Science of Food and Agriculture, 82, 217-221.

McDougall, G. J., Dobson, P., Smith, P., Blake, A., \& Stewart, D. (2005). Assessing potential bioavailability of raspberry anthocyanins using an in vitro digestion system. Journal of Agricultural and Food Chemistry, 53, 5896-5904.

McDougall, G. J., Fyffe, S., Dobson, P., \& Stewart, D. (2007). Anthocyanins from red cabbage - Stability to simulated gastrointestinal digestion. Phytochemistry, 68, 1285-1294.

McGhie, T. K., \& Walton, M. C. (2007). The bioavailability and absorption of anthocyanins: Towards a better understanding. Molecular Nutrition \& Food Research, 51, 702-713.

Mullen, W., Edwards, C. A., Serafini, M., \& Crozier, A. (2008). Bioavailability of pelargonidin-3-O-glucoside and its metabolites in humans following the ingestion of strawberries with and without cream. Journal of Agricultural and Food Chemistry, 56, 713-719.

Neilson, A. P., George, J. C. Janle, E. M., Mattes, R. D., Rudolph, R., Matusheski, N. V., et al. (2009). Influence of chocolate matrix composition on cocoa flavan-3-ol bioaccessibility in vitro and bioavailability in humans. Journal of Agricultural and Food Chemistry, 57, 9418-9426.

Ortega, N., Reguant, J., Romero, M. P., Macia, A., \& Motilva, M. J. (2009). Effect of fat content on the digestibility and bioaccessibility of cocoa polyphenol by an in vitro digestion model. Journal of Agricultural and Food Chemistry, 57, 5743-5749.

Perez-Vicente, A., Gil-Izquierdo, A., \& Garcia-Viguera, C. (2002). In vitro gastrointestinal digestion study of pomegranate juice phenolic compounds, anthocyanins and vitamin C. Journal of Agricultural and Food Chemistry, 50, 2308-2312.

Prakash, C. V. S., \& Prakash, I. (2011). Bioactive chemical constituents from pomegranate (Punica granatum) juice, seed and peel: A review. International Journal of Research in Chemistry and Environment, 1, 1-18.

Reddy, V. C., Vidya Sagar, G. V., Sreeramulu, D., Venu, L., \& Raghunath, M. (2005). Addition of milk does not alter the antioxidant activity of black tea. Annals of Nutrition and Metabolism, 49, 189-195

Richelle, M., Tavazzi, I., \& Offord, E. (2001). Comparison of the antioxidant activity of commonly consumed polyphenolic beverages (coffee, cocoa, and tea) prepared per cup serving. Journal of Agricultural and Food Chemistry, 49, 3438-3442.

Santiago, L. G., Carrara, C., \& González, R. J. (2005). Interaction of soy protein isolate and meat protein in a model emulsion system: Effect of emulsification order and characteristics of soy isolate used. Food Science and Technology International, 11, 79-88. 
Seeram, N.P., Adams, L. S., Henning, S. M., Niu, Y., Zhang, Y., Nair, M. G., et al. (2005). In vitro antiproliferative, apoptotic and antioxidant activities of punicalagin, ellagic acid and a total pomegranate tannin extract are enhanced in combination with other polyphenols as found in pomegranate juice. Journal of Nutritional Biochemistry, 16, 360-367.

Serafini, M., Bugianesi, R., Maiani, G., Valtuena, S., Santis, S. D., \& Crozier, A. (2003). Plasma antioxidants from chocolate. Nature, 424, 1013

Serafini, M., Ghiselli, A., \& Ferro-Luzzi, A. (1996). In vivo antioxidant effect of green and black tea in man. European Journal of Clinical Nutrition, 50, 28-32.

Serafini, M., Testa, M. F., Villano, D., Pecorari, M., Wieren, K. V., Azzini, E., et al. (2009). Antioxidant activity of blueberry fruit is impaired by association with milk. Free Radical Biology \&' Medicine, 46, 769-774.

Tagliazucchi, D., Verzelloni, E., Bertolini, D., \& Conte, A. (2009). In vitro bio-accessibility and antioxidant activity of grape polyphenols. Food Chemistry, 120, 599-606.

Tehranifor, A., Zarei, M., Nemati, Z., Esfandiyari, B., \& Vazifeshenas, M. R. (2010). Investigation of physico-chemical properties and antioxidant activity of twenty Iranian pomegranate (Punica granatum L.) cultivars. Scientia Horticulturae, 126, 180-185.

Toydemir, G., Boyacioglu, D., Capanoglu, E., Van der Meer, I. M., Tomasseni, M. M. M., Hall, R. D., et al. (2013). Investigating the transport dynamics of anthocyanins from unprocessed fruit and processed fruit juice from sour cherry (Prunus cerasus L.) across intestinal epithelial cells. Journal of Agricultural and Food Chemistry, 61, 11434-11441.
Van het Hof, K. H., Kivits, G. A., Weststrate, J. A., \& Tijburg, L. B. (1998). Bioavailability of catechins from tea: The effect of milk. European Journal of Clinical Nutrition, 52, 356-359.

Velioglu, Y. S., Mazza, G., Gao, L., \& Oomah, B.D. (1998). Antioxidant activity and total phenolics in selected fruits, vegetables and grain products. Journal of Agricultural and Food Chemistry, 46, 4113-4117.

Walton, M. C., Hendriks, W. H., Broomfield, A.M., \& McGhie, T. K. (2009). Viscous food matrix influences absorption and excretion but not metabolism of blackcurrant anthocyanins in rats. Journal of Food Science, 74, H22-H29.

Wolfe, K. L., Kang, X., He, X., Dong, M., Zhang, Q., \& Liu, R. H. (2008). Cellular antioxidant activity of common fruits. Journal of Agricultural and Food Chemistry, 56, 8418-8426.

Yang, M., Koo, S. I., Song, W. O., \& Chun, O. K. (2011). Food matrix affecting anthocyanin bioavailability: Review. Current Medicinal Chemistry, 18, 291-300.

Yi, W., Akoh, C. C., Fischer, J., \& Krewer, G. (2006). Absorption of anthocyanins from blueberry extracts by Caco-2 human intestinal cell monolayers. Journal of Agricultural and Food Chemistry, 54, 5651-5658.

Zhang, H., Zheng, J., Liu, X., Ding, Q., Jiang, L., Guo, H., et al. (2012). Milk protein and fat play different roles in affecting the bioavailability and the antioxidant activity of jujube juice phenolics in rats. Molecular Nutrition and Food Research, 56, 1511-1519. 